\title{
Microbial Spoilage and Preservation of Wine: Using Weapons from Nature's Own Arsenal - A Review
}

\author{
M. du Toit and I.S. Pretorius \\ Matieland (Stellenbosch), South Africa \\ Submitted for publication: April 2000 \\ Accepted for publication: August 2000 \\ Key words: Wine spoilage, spoilage microorganisms, preservation, natural preservatives
}

Institute for Wine Biotechnology and Department of Viticulture \& Oenology, University of Stellenbosch, Private Bag X1, 7602

\begin{abstract}
The winemaking process includes multiple stages at which microbial spoilage can occur, altering the quality and hygienic status of the wine and rendering it unacceptable. The major spoilage organisms include species and strains of the yeast genera Brettanomyces, Candida, Hanseniaspora, Pichia, Zygosaccharomyces etc., the lactic acid bacterial genera Lactobacillus, Leuconostoc, Pediococcus, etc. and the acetic acid bacterial genera Acetobacter and Gluconobacter. The faults caused include bitterness and off-flavours (mousiness, ester taint, phenolic, vinegary, buttery, geranium tone), and cosmetic problems such as turbidity, viscosity, sediment and film formation. These spoilage organisms can also affect the wholesomeness of wine by producing biogenic amines and precursors of ethyl carbamate. The judicious use of chemical preservatives such as sulphur dioxide $\left(\mathrm{SO}_{2}\right)$ during the winemaking process decreases the risk of microbial spoilage, but strains vary considerably in their $\mathrm{SO}_{2}$ sensitivity. There is, moreover, mounting consumer bias against chemical preservatives, and this review focuses on the possible use of biopreservatives in complying with the consumers' demand for "clean and green" products.
\end{abstract}

\section{INTRODUCTION}

The association of microorganisms with the fermentation of alcoholic beverages dates back to Biblical times. The first observation of microbes in fermenting wine was made possible by the development of the microscope by Antonie van Leeuwenhoek in the mid-1600's, and the microbiology of wine was explained in the 1850's when Louis Pasteur observed the conversion of grape juice into wine by the action of yeast. He also saw that certain bacteria causing spoilage could grow in this medium (Fleet, 1998). The microorganisms involved are at the core of the winemaking process, whether for good or ill; they affect the quality of wine and they determine the economic balance sheet of wine production. Wine spoilage microbes are those microorganisms found at the wrong place and the wrong time, including microbes which are normally desirable and contribute to the quality of the end product. The winemaking process is a complex ecological niche where the biochemistry and interaction of yeasts, bacteria, fungi and their viruses play a pivotal role in the final product. It is therefore crucial to understand the conditions under which a specific microorganism can cause spoilage, as well as the offflavours, odours and colour changes associated with the specific spoilage condition. With that understanding it will be possible to combat wine spoilage effectively and develop new preservation methods.

This article summarises the most important wine spoilage microorganisms, along with the preservation methods used to eliminate or minimise wine spoilage. Biological preservatives (bio-preservation) will be discussed as an alternative to chemical preservation.

\section{ORIGINS OF WINE SPOILAGE MICROORGANISMS}

There are three stages at which microorganisms can enter the winemaking process and exert an influencing effect on the quali- ty of the end product. The first stage involves the raw material. The grapes are in direct contact with the winery equipment (crushers, presses, tanks, pipes, pumps, filtration units, etc.), and when not properly sanitised the equipment will serve as an inoculant of the grape juice. The grapes delivered to a winery are not all in a healthy state, and this will affect the natural biodiversity of the microorganisms present in the juice. Consider acetic acid bacteria (AAB): on healthy grapes Gluconobacter oxydans is the major species, detected at $10^{2} \mathrm{cfu} / \mathrm{g}$. Grapes infected with Botrytis cinerea, however, harbour $10^{6} \mathrm{cfu} / \mathrm{g}$ of mainly Acetobacter aceti and Acetobacter pasteurianus with fewer cells of G. oxydans (Drysdale \& Fleet, 1988; Fugelsang, 1997). The natural microflora are affected indirectly by external conditions such as grape variety, the state of grapes at harvest, the health of the grapes (e.g., physical damage due to birds, insects, harvesting and mould attack), temperature, rainfall, soil, the use of insecticides and fungicides, and other viticultural practices (Fleet \& Heard, 1993; Fleet, 1998; Pretorius et al., 1999).

The second stage of spoilage may occur during fermentation. At this point the grape juice contains the natural flora of the grapes along with the flora harboured by the wine cellar and its equipment. The composition of the grape juice (high sugar and acid content, and low $\mathrm{pH}$ ) and the addition of sulphur dioxide $\left(\mathrm{SO}_{2}\right)$ to the juice exerts selective pressure on the development of yeasts and bacteria during alcoholic fermentation. Saccharomyces cerevisiae is the dominant yeast during fermentation, and the increase in ethanol concentrations further suppresses the development of certain fungi and bacteria. In natural fermentation the initiators of this process are yeast species belonging to the genera Candida, Hanseniaspora, Kloeckera and Metschnikowia, and less frequently Kluyveromyces and Pichia (Fugelsang, 1997; Fleet, 1998; Pretorius et al., 1999). These nonSaccharomyces yeasts are ethanol-sensitive and die off as soon as 
the ethanol concentration starts to increase during the fermentation process, but with numbers as high as $10^{6}-10^{7} \mathrm{cfu} / \mathrm{ml}$ before death, they significantly influence the composition of the wine (Fleet \& Heard, 1993; Kunkee \& Bisson, 1993). pH is a crucial factor at this stage. At a wine $\mathrm{pH}>3.6$ the growth of lactic acid bacteria (LAB), especially Lactobacillus, Leuconostoc and Pediococcus spp., as well as AAB is enhanced, and this may be detrimental to the quality of the wine (Lafon-Lafourcade et al., 1983; Joyeux et al., 1984a; Wibowo et al., 1985; Fugelsang, 1997; Fleet, 1998).

The third stage at which the product may be susceptible to spoilage is post-fermentation. Here, spoilage may occur in the bottle or during storage in oak barrels. During this stage, the critical factors are good cellar sanitation, exclusion of oxygen and the correct dosage of antimicrobial agents to ensure a stable product that will withstand attack from spoilage yeasts and bacteria (Sponholz, 1993; Boulton et al., 1996; Fleet, 1998). The wine can also be affected at this stage by fungi and species of Actinomyces and Streptomyces present in the corks or oak barrels (Lee \& Simpson, 1993).

\section{SPOILAGE BY YEASTS}

The Yeast, A Taxonomic Study by Kurtzman \& Fell (1998) describes one hundred yeast genera representing over 700 species. Only twelve of the yeast genera are associated with grapes or wine, emphasising the degree of specialisation needed to survive in the hostile wine environment. Identification of yeast species is of utmost importance to oenologists assessing the risk of potential spoilage. The term "wine yeasts" applies to those Saccharomyces yeasts which can perform a complete fermentation of grape juice without the production of off-flavours. These yeasts are tolerant to high concentrations of ethanol and sugar. The term "wild yeasts" applies to those non-Saccharomyces yeasts which can perform a partial alcoholic fermentation, often

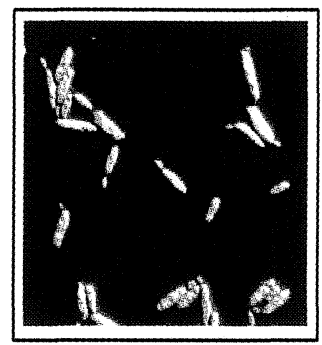

(a)

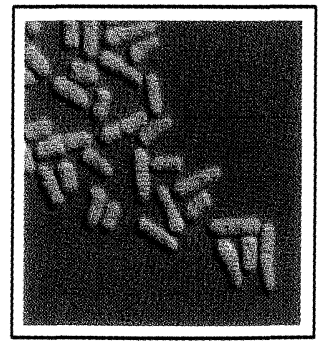

(c)

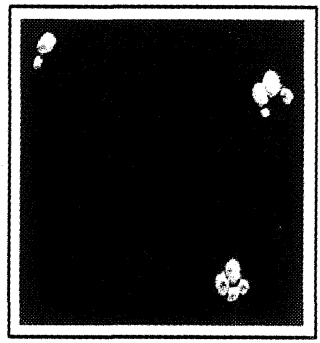

(b)

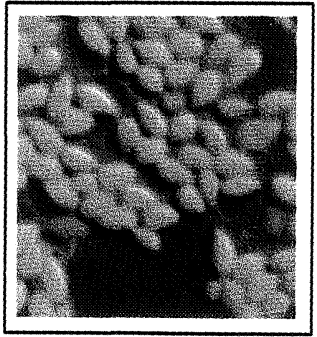

(d)

\section{FIGURE 1}

Photomicrographs of yeasts often associated with wine. (a) Brettanomyces intermedius, (b) Saccharomyces cerevisiae, (c) Schizosaccharomyces pombe and (d) Zygosaccharomyces bailii. with the formation of esters. Both these types of yeasts can bring about spoilage (Table 1). The yeast genera that are often found in wine include Brettanomyces and its sporulating form Dekkera, Saccharomyces, Schizosaccharomyces and Zygosaccharomyces (Boulton et al., 1996) (Fig. 1).

Zygosaccharomyces was formerly known as Saccharomyces and was recognised as a separate genus for the first time in 1984 by Kreger-van $\mathrm{Rij}$ in the third edition of The Yeast, A Taxonomic Study. In the latest edition by Kurtzman \& Fell (1998), eight species are included in this genus, of which only four are associated with grape must and wine: Zygosaccharomyces bailii, Zygosaccharomyces bisporus, Zygosaccharomyces rouxii and Zygosaccharomyces florentinus (Boulton et al., 1996; Fugelsang, 1998; Kurtzman \& Fell, 1998). Zygosaccharomyces is osmophilic, with the ability to grow at high sugar concentrations and to ferment grape juice to dryness. Z. bailii is highly resistant to preservatives ( $\mathrm{SO}_{2}$, sorbic and benzoic acid) used in grape juice and wine, and possesses a high ethanol tolerance $(>15 \%)$ and a low $\mathrm{pH}$ tolerance $(<2.0)$, which makes it a difficult spoilage yeast (Thomas \& Davenport, 1985; Fugelsang, 1998).

Brettanomyces is the non-sexual, non-sporulating form of Dekkera. According to Kurtzman \& Fell (1998), only Brettanomyces intermedius and Dekkera intermedia have been associated with grape juice and wine. These yeasts are most commonly found within the wood cooperage (Boulton et al., 1996). Both species of the genera are able to perform alcoholic fermentation of grape juice, albeit very slowly.

The genera regarded as "wild yeasts" are Candida, Debaryomyces, Hanseniaspora, Hansenula, Kloeckera,
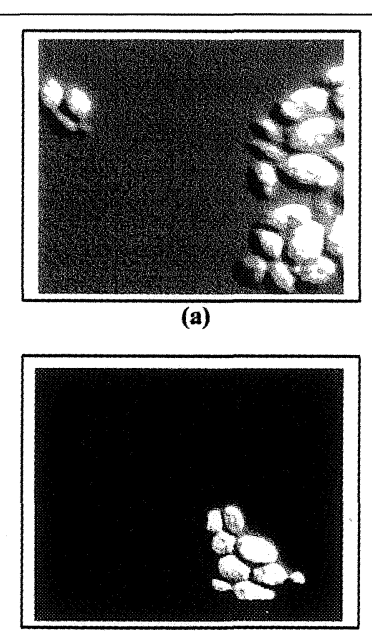

(c)

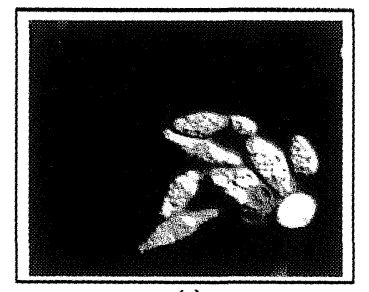

(e)

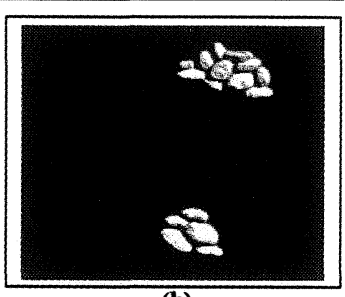

(b)

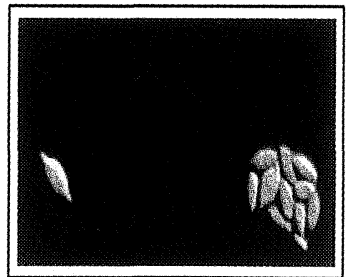

(d)

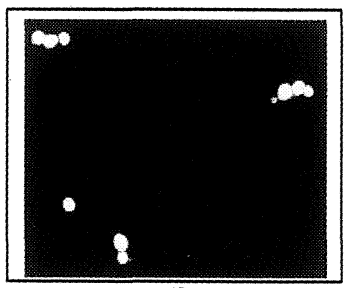

(I)

\section{FIGURE 2}

Photomicrographs of the non-Saccharomyces yeasts. (a) Candida, (b) Debaryomyces, (c) Hansenula anomala, (d) Kloeckera apiculata, (e) Saccharomycodes ludwigii and (f) Torulaspora delbrueckii. 
TABLE 1

Spoilage of wines by yeasts.

\begin{tabular}{ll}
\hline Yeasts & \multicolumn{2}{c}{ Spoilage } \\
\hline Brettanomyces intermedius & $\begin{array}{l}\text { Produces volatile phenols causing } \\
\text { medicinal, phenolic, horsy and barnyard } \\
\text { Anamorph: Dekkera intermedia } \\
\text { taints; mousy off-flavour results from } \\
\text { isomers of tetrahydropyridines and } \\
\text { produces high levels of acetic acid }\end{array}$ \\
Candida spp. & Wine exposed to air will develop film \\
C. vini & layers; oxidize ethanol with resulting high \\
C. stellata & concentrations of acetaldehyde, volatile \\
C. pulcherrima & acids and esters \\
C. &
\end{tabular}

\section{Reference}

C. krusei

Anamorph: Issatchenkia orientalis

Hanseniaspora uvarum

Anamorph: Kloeckera apiculata

Hansenula anomala (now Pichia anomala)

\section{Metschnikowia pulcherrima}

\author{
Pichia spp. \\ $P$. farinosa \\ $P$. membranaefaciens \\ $P$. vini
}

Saccharomyces cerevisiae

Saccharomycodes ludwigii

Schizosaccharomyces pombe

Zygosaccharomyces bailii
High levels of acetic acid and its esters, and produces killer toxins

High levels of acetic acid; ester taint, large amounts of ethyl acetate, isoamyl acetate and methylbutyl acetate and development of film layer

Grows as a film layer and produces high levels of ethylacetate and acetaldehyde

Produces chalky film layer and high levels of acetaldehyde

Re-fermentation of wine with residual sugars

High concentrations of acetaldehyde, flocculent masses settle as chunks and form a slimeness

Re-fermentation of bottled wine; deacidification

Secondary fermentation of wine with large amounts of $\mathrm{CO}_{2}$; turbidity and sediment; high levels of acetic acid and esters
Fleet, 1992; Fugelsang, 1997; Zoecklein et al., 1995

Sponholz et al., 1990; Fleet, 1992; Boulton et al., 1996

\section{Sponholz, 1993}

Fleet, 1992; Zoecklein et al., 1995

Fleet, 1992; Boulton et al., 1996

Fleet, 1992; Boulton et al., 1996

Boulton et al., 1996; Fugelsang, 1997; Kunkee \& Bisson, 1993

Soles et al., 1982; Sponholz, 1993; Boulton et al., 1996; Fugelsang, 1996, 1997, 1998
Metschnikowia, Pichia, Saccharomycodes and Torulaspora (Fleet, 1992, 1993, 1998; Sponholz, 1993; Boulton et al., 1996; Fugelsang, 1997) (Fig. 2). According to the latest yeast taxonomy, wine related species of the genus Hansenula have been reassigned to Pichia (Kurtzman \& Fell, 1998).

\section{Re-fermentation}

Saccharomyces is regarded as a spoilage organism only if it is found in the wrong place at the wrong time (e.g. in a bottle of semi-sweet wine) causing re-fermentation. Schizosaccharomyces pombe has been associated with wine spoilage when growing in bottled wine and forming a sediment at the bottom of the bottle (Boulton et al., 1996). The yeast Z. bailii is one of the major wine spoilage yeasts, re-fermenting juice or wine during storage (Peynaud \& Domerq, 1959; Thomas \& Davenport, 1985;
Sponholz, 1993; Fugelsang, 1996, 1998). Saccharomycodes ludwigii, found in bottled wines, is often regarded as the winemaker's nightmare (Thomas, 1993). This yeast species is highly tolerant to ethanol and resistant to $\mathrm{SO}_{2}$ and sorbate. It produces high levels of acetaldehyde and has been isolated as a slimy flocculent mass (Boulton et al., 1996).

\section{Ester formation}

Hansenula anomala (now known as Pichia anomala), Kloeckera apiculata and Hanseniaspora uvarum are mainly associated with the ester taint of faulty wines, which correlates with large amounts of acetic acid. These three species are associated with grape juice and result in spoilage at the early stages of alcoholic fermentation (Fleet, 1990; Boulton et al., 1996). The ester taint can be linked to the presence of ethyl acetate and methylbutyl 
acetate, which are most prominent in wines possessing this offflavour (Sponholz \& Dittrich, 1974; Sponholz et al., 1990; Boulton et al., 1996). Wines with concentrations of $>200 \mathrm{mg} / \mathrm{L}$ ethyl acetate and $0.6 \mathrm{mg} / \mathrm{L}$ of acetate are regarded as spoiled.

Growth of $Z$. bailii may also lead to wine with an increase in acetic and succinic acid, a decrease of L-malic acid and a concomitant reduction in total acidity and an altered ester concentration (Shimazu \& Watanabe, 1981; Kuczynski \& Radler, 1982; Soles et al., 1982; Sponholz, 1993; Boulton et al., 1996; Fugelsang, 1997).

\section{Hydrogen sulphide and volatile sulphur compounds}

Sulphur-containing compounds play a significant role in the flavour of wine due to their high volatility, reactivity and potency at low threshold values (Schutte, 1975; Rauhut, 1993). These compounds are responsible for off-flavours that have been described as rotten eggs, rubbery, onion, skunky aroma, garlic and cabbage (Zoecklein et al., 1995; Boulton et al., 1996). Hydrogen sulphide $\left(\mathrm{H}_{2} \mathrm{~S}\right)$ is produced by yeasts during fermentation through the sulphate reduction pathway and has a flavour threshold of $50-80 \mathrm{mg} / \mathrm{L}$ and when exceeding this value will produce the rotten egg off-flavour (Wenzel et al., 1980). The ability of yeasts to produce $\mathrm{H}_{2} \mathrm{~S}$ varies between strains and is influenced by environmental factors such as must composition (solids, vitamins and free amino nitrogen), fermentation temperature, wine $\mathrm{pH}$ and the use of fungicides containing elemental sulphur (Henschke \& Jiranek, 1993; Rauhut, 1993; Zoecklein et al., 1995; Rauhut et al., 1996). The mechanism by which yeasts produces $\mathrm{H}_{2} \mathrm{~S}$ is linked to both sulphur and nitrogen metabolism and is reviewed by Rauhut (1993), Pretorius (2000) and Lambrechts \& Pretorius (2000).

Hydrogen sulphide can react with other wine components to produce mercaptans, thiols and disulphides which are perceived as skunky, onion, cabbage, rubber and garlic off-flavours. These compounds have very low threshold values such as $0.02 \mu \mathrm{g} / \mathrm{L}$ for methyl mercaptan (review Lambrechts \& Pretorius, 2000; Rauhut, 1993).

It is thus important to select $S$. cerevisiae yeast strains that produce limited amounts of hydrogen sulphide to reduce the risks of wine containing high levels of volatile sulphur compounds that will render the wine quality unacceptable. It is also important to determine the contribution of non-Saccharomyces yeasts to this default.

\section{Volatile acidity}

The major volatile acid in wine is acetic acid (> 90\%) (Radler, 1993). Acetic acid has a threshold value of 0.7 to $1.1 \mathrm{~g} / \mathrm{L}$ depending on the style of wine and above these values it becomes objectionable (Zoecklein et al., 1995). High levels of volatile acidity may result from the indigenous wine yeasts and wild yeasts, as well as lactic acid - and acetic acid bacteria, which will be discussed separately in the review (Radler, 1993; Boulton et al., 1996). Acetic acid is formed as a by-product by yeasts during the early stages of alcoholic fermentation. Saccharomyces strains displayed variation in their production of acetate and this phenomenon is influenced by fermentation temperature, $\mathrm{pH}$, juice composition (sugar and nitrogen levels), levels of acetyl-CoA synthetase enzyme and the presence of other microorganisms (Shimazu \& Watanabe, 1981; Zoecklein et al., 1995; Boulton et al., 1996).
Yeasts involved in the acetification of wine above objectionable levels include Brettanomyces and its anamorph Dekkera, P. anomala, K. apiculata and Candida krusei (Shimazu \& Watanabe, 1981; Zoecklein et al., 1995).

\section{Formation of volatile phenols}

Descriptive words for wines contaminated with Brettanomyces include mousy, barnyard-like, horsy, wet dog, tar, tobacco, creosote, leathery and pharmaceutical. Contaminated wines often display an increase in volatile acidity, due to the oxidation of acetaldehyde to acetic acid instead of ethanol. Most of the abovementioned descriptors, e.g. phenolic, smoky, horsy, elastoplast, can be ascribed to the concentrations of volatile phenols such as vinylphenols [4-vinylguaiacol $(>750 \mu \mathrm{g} / \mathrm{L})$ and 4-vinylphenol $(>440 \mu \mathrm{g} / \mathrm{L})$ ] in white wines and ethylphenols [4-ethylguaiacol $(>100 \mu \mathrm{g} / \mathrm{L})$ and 4-ethyl phenol $(>600 \mu \mathrm{g} / \mathrm{L})]$ produced in red wines (Heresztyn, 1986a; Chatonnet et al., 1992, 1995; Boulton et al., 1996). These volatile phenols are produced by decarboxylation (cinnamate decarboxylase) and reduction of hydroxycinnamic acids such as p-coumaric- and ferulic acid.

\section{Mousiness}

The mousy taint resulting from Brettanomyces growth is discussed under spoilage by $\mathrm{LAB}$, as the mechanism is the same.

\section{Film formation}

Some yeasts, called film yeasts, can form a film layer on top of stored wine; species of the genera Candida, Metschnikowia and Pichia have been associated with this trait (Sponholz, 1993; Fugelsang, 1997). These yeasts not only create a cosmetic problem, they may also be detrimental to the quality of wine, imparting an oxidised flavour due to the production of acetaldehyde. The development of these yeasts is highly dependent on available oxygen and will thus proliferate in wine exposed to air and in partially filled barrels. The main products formed from ethanol by these film yeasts are acetic acid, acetaldehyde and acetate esters (Sponholz \& Dittrich, 1974).

\section{Deacidification}

The acidity of wine is important as it has a direct impact on the flavour of the wine and indirectly affects the $\mathrm{pH}$, colour, stability and general quality of the wine. Titratable acidity is influenced by grape varieties, climatic conditions, viticultural practises and the ripeness of the grape berries (Zoecklein et al., 1995). Grape juice and wine contain a variety of organic and inorganic acids. The main organic acids associated with wine are tartaric, malic, citric, acetic, lactic and succinic (Radler, 1993). Malic and tartaric acid accounts for $90 \%$ of the titratable acidity of grapes. In cooler climatic regions such as Europe, Canada and the USA the titratable acidity is high and the $\mathrm{pH}$ low, whereas in warmer regions such as South Africa, Australia and South America the situation is reversed. Thus the deacidification of wine is important in cooler climate regions to ensure a product that is balanced and not perceived as tart due to high levels of acidity and low $\mathrm{pH}$. Deacidification of wine can be obtained by the biological conversion of malic acid to lactic acid and carbon dioxide. This process is called malolactic fermentation and is mainly mediated by lactic acid bacteria, especially Oenococcus oeni (HenickKling, 1993; Lonvaud-Funel, 1995). The degradation of malic acid by yeasts has been studied and vary considerably between strains. The wine yeast $S$. cerevisiae is a weak utiliser of malic 
acid, as is wine related species of the genera Candida, Hansenula, Kloeckera and Pichia, whereas S. pombe, Schizosaccharomyces malidevorans and Z. bailii can strongly degrade malate (Rodriguez \& Thornton, 1990; Radler, 1993).

$S$. pombe has been exploited to be used for biological deacidification but it has a higher fermentation optimum $\left(30^{\circ} \mathrm{C}\right)$, which may negatively affect the organoleptic quality of wine, and produce off-flavours (Benda \& Schmitt, 1969; Gallander, 1977; Radler, 1993; Zoecklein et al., 1995). This problem is being addressed in the new millennium by genetic engineering of wine yeasts, which will enable them to degrade malic acid while performing the alcoholic fermentation (Pretorius, 2000).

A secondary effect of deacidification that has been noted is the loss in red colour due to an increase in $\mathrm{pH}$. If over-deacidification occurs and the $\mathrm{pH}$ has increased drastically the colour may change from full red to a bluish hue (Boulton et al., 1996).

Thus the fermentation of wines containing low levels of malic acid with malate-degrading yeasts will negatively affect the wine quality due to a loss of acidity and indirectly encourage spoilage organisms to grow as an increase in $\mathrm{pH}$ will be evident.

\section{Formation of ethyl carbamate}

L-Arginine is one of the major amino acids present in grape juice and wine, and is degradable by microorganisms. Arginine is degraded to ornithine, ammonia and carbon dioxide in $S$. cerevisiae by the arginase enzyme (Ough et al., 1988b). Urea is formed as an intermediate product and is secreted by certain yeasts into the wine, where the reaction between ethanol and urea produces ethyl carbamate (also known as urethane), which is considered to be a carcinogen (Ough et al., 1988a; Monteiro \& Bisson, 1991). The secretion of urea by yeasts is enhanced at elevated fermentation temperatures, and high concentrations of ammonia effect the re-adsorption of urea by yeast (Ough et al., 1988 b 1991). Young wines contain the precursors required to form ethyl carbamate, and high levels of this carcinogen can occur in wine during ageing or storage at elevated temperatures. Beverages such as sherries, dessert wines and distilled products, which contain higher alcohol levels than table wines, also tend to have higher levels of ethyl carbamate. S. cerevisiae can thus affect the wholesomeness of wine by providing precursors for the formation of ethyl carbamate; it is therefore important to select wine yeast strains that are low urea producers and to minimise viticultural practices that can affect the urea levels in wine.

\section{SPOILAGE BY LACTIC ACID BACTERIA}

LAB play a pivotal role in the secondary fermentation of wine by conducting malolactic fermentation (MLF) (Wibowo et al., 1985; Kunkee, 1991; Henick-Kling, 1993; Lonvaud-Funel, 1995), but they can also be detrimental to wine quality as spoilage microorganisms if proliferation of certain LAB occurs at the wrong time during the winemaking process.

$\mathrm{LAB}$ are Gram-positive, catalase-negative, non-motile, nonsporeforming, rod- and coccus shaped. They produce mainly lactic acid as the end product of carbohydrate fermentation. Therefore, the LAB are divided into three groups according to their metabolic activity: obligately homofermentative, facultatively heterofermentative and obligately heterofermentative. The $\mathrm{LAB}$ associated with grape juice and wine belong to four genera: Lactobacillus, Leuconostoc, Oenococcus and Pediococcus
(Fig. 3) (Amerine \& Kunkee, 1968; Kandler \& Weiss, 1986; Fleet, 1993; Stiles \& Holzapfel, 1997; Lonvaud-Funel, 1999). Several species of these four genera have been isolated from wine and have been associated with wine spoilage (Table 2).

Environmental conditions determine the native LAB populations and the succession of species and strains before, during and after alcoholic fermentation (Fleet et al., 1984). Due to their fastidious nutritional requirements, it is not surprising that they are found in low numbers $\left(<10^{3} \mathrm{cfu} / \mathrm{g}\right)$ on healthy grapes and the subsequent must (Sponholz, 1993; Lonvaud-Funel, 1995, 1999; Fleet, 1998). Spoiled grapes harbouring AAB and fungi stimulate the growth of LAB (Fugelsang, 1997). The LAB can tolerate the stresses of wine; they have adapted to low $\mathrm{pH}$, presence of ethanol, $\mathrm{SO}_{2}$, low temperature and the availability of nutrients (Wibowo et al., 1985). During alcoholic fermentation the LAB may not increase in numbers; this is due to the interaction with yeast, the production of fatty acids by yeast, the increase of ethanol concentrations and the production of bacteriocins by certain LAB (Lafon-Lafourcade et al., 1983; Lonvaud-Funel et al., 1988; Lonvaud-Funel \& Joyeux, 1993). After the lag phase, the LAB may proliferate in the wine and can reach populations of $10^{6}-10^{8} \mathrm{cfu} / \mathrm{ml}$ (Fugelsang, 1997; Fleet, 1998). O. oeni dominates wines of low $\mathrm{pH}$ (3.0-3.5); high $\mathrm{pH}$ (>3.5) wines contain species of the genera Lactobacillus and Pediococcus (Davis et al., 1985; Edwards \& Jensen, 1992). Having survived alcoholic fermentation, these opportunists await the chance to grow and exert an effect that may be detrimental to the quality of the wine.

The role of LAB in wine spoilage is well recognised, to assess the risk associated with the residing species, it is important to

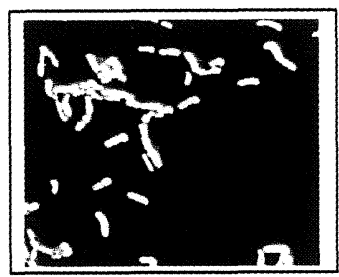

(a)

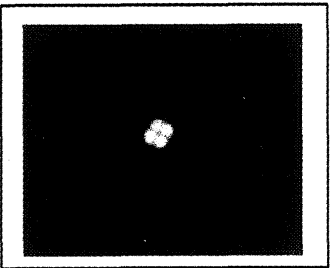

(c)

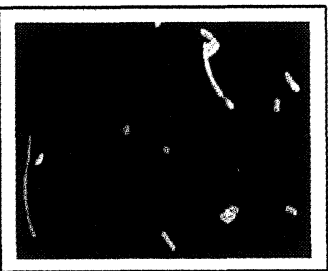

(e)

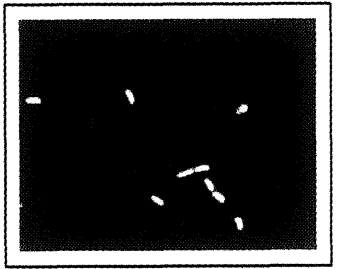

(b)

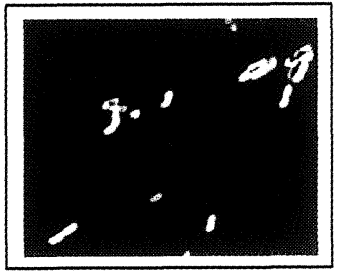

(d)

\section{FIGURE 3}

Photomicrographs of lactic acid bacteria. (a) Lactobacillus fermentum, (b) Lactobacillus kunkeei, (c) Pediococcus, (d) Leuconostoc mesenteroides, and (e) Oenococcus oeni. 
TABLE 2

Spoilage of wines by bacteria.

\begin{tabular}{lll}
\hline Bacteria & Spoilage & Reference \\
\hline
\end{tabular}

Lactic acid bacteria:

Lactobacillus brevis

Lactobacillus

cellobiosus,

Lactobacillus hilgardii

Lactobacillus kunkeei

Lactobacillus plantarum

Lactobacillus trichodes

Leuconostoc

mesenteroides

Oenococcus oeni

Pediococcus damnosus

Pediococcus parvulus

Pediococcus pentosaceus

\section{Acetic acid bacteria:}

Acetobacter aceti

Acetobacter pasteurianus

Gluconobacter oxydans
Produces ethyl carbamate precursors; tartaric acid utilization; acidification of wine through the production of acetic and lactic acids; mannitol is formed by the reduction of fructose; mousy taints

Mousy taints from tetrahydropyridine; Sponholz, 1993 bitterness arising from glycerol metabolism

Production of high levels of acetic acid that is implicated in stuck fermentations

Tartrate degradation; produce elevated diacetyl levels

Flocculent growth

Forms ropiness; bitterness from glycerol metabolism

Degrades arginine to produce ethyl carbamate precursors; produces histamine as a biogenic amine; implicated in stuck fermentation; buttery flavour due to increased diacetyl levels

Produces histamine, synthesise polysaccharides

Acrolein formation from glycerol Davis et al., 1988 contribute to bitterness

Produce polysaccharides that increase viscosity

Oxidation of ethanol to acetaldehyde and acetic acid; production of ethyl acetate; production acetoin from lactic acid; metabolism of glycerol to dihydroxyacetone; ropiness
Sponholz, 1993; Liu \& Pilone, 1998

Edwards et al., 1998a, 1999a

Martineau \& Henick-Kling, 1995

Amerine \& Kunkee, 1968

Sponholz, 1993; Fugelsang, 1997

Liu et al., 1994; LonvaudFunel \& Joyeux, 1994; Huang et al., 1996; Nielsen \& Prahl, 1997; Edwards et al., 1998b

Delfini, 1989; Lonvaud-Funel et al., 1993

Manca de Nadra \& Strasser de Saad, 1995

Sponholz, 1993; Boulton et al., 1996; Fugelsang 1997

Sponholz, 1993; Boulton et al., 1996 
identify and enumerate the bacteria during the different stages of vinification. Conventionally, LAB are identified by their morphological and biochemical characteristics. However, results obtained are often ambiguous and the methods involved are time consuming. Other methods have been applied with success to the identification of wine-associated LAB, including protein fingerprinting, peptidoglycan of the cell walls and lactate dehydrogenase enzyme patterns (Irwin et al., 1983; Tracey \& Britz, 1987; Dicks \& Van Vuuren, 1988). Media have been developed for easy detection of certain characteristics of wine LAB, and pre-spoilage markers have been identified (Pilone et al., 1991; De Revel et al., 1994). Recently molecular techniques have been employed to identify wine LAB by DNA level, and the results obtained are less controversial than for other methods (Lonvaud-Funel et al., 1991a, b; Sohier \& Lonvaud-Funel, 1998; Zapparoli et al., 1998; Sohier et al., 1999). The design of DNA probes to detect specific characteristics have been successfully applied to oenology (Lonvaud-Funel et al., 1993; Le Jeune et al., 1995; Zapparoli et al., 1998; Groisillier \& Lonvaud-Funel, 1999).

\section{Acid formation}

LAB can increase the acid content of wine by producing lactic acid and acetic acid. The D-lactic acid is associated with spoilage, as the L-lactic acid is produced during MLF (Sponholz, 1993; Fugelsang, 1997). The homofermentative LAB reduces hexose sugars to lactic acid via the Embden-Meyerhof-Parnas (glycolytic) pathway. The formation of D-lactic acid arises from the reduction of pyruvic acid and is performed by homofermentative species of lactobacilli and pediococci. Heterofermentative lactobacilli, Leuconostoc and Oenococcus spp. produce D-lactic acid and acetic acid through the 6-phosphogluconate pathway (Fig. 4). Strasser de Saad \& Manca de Nadra (1992) showed that the production of acetic acid in $O$. oeni (formerly known as Leuconostoc oenos; Dicks et al., 1995) correlated with the metabolism of fructose. Acetic acid associated with volatile acidity (VA) is thought to be different, due to the presence of high amounts of ethyl

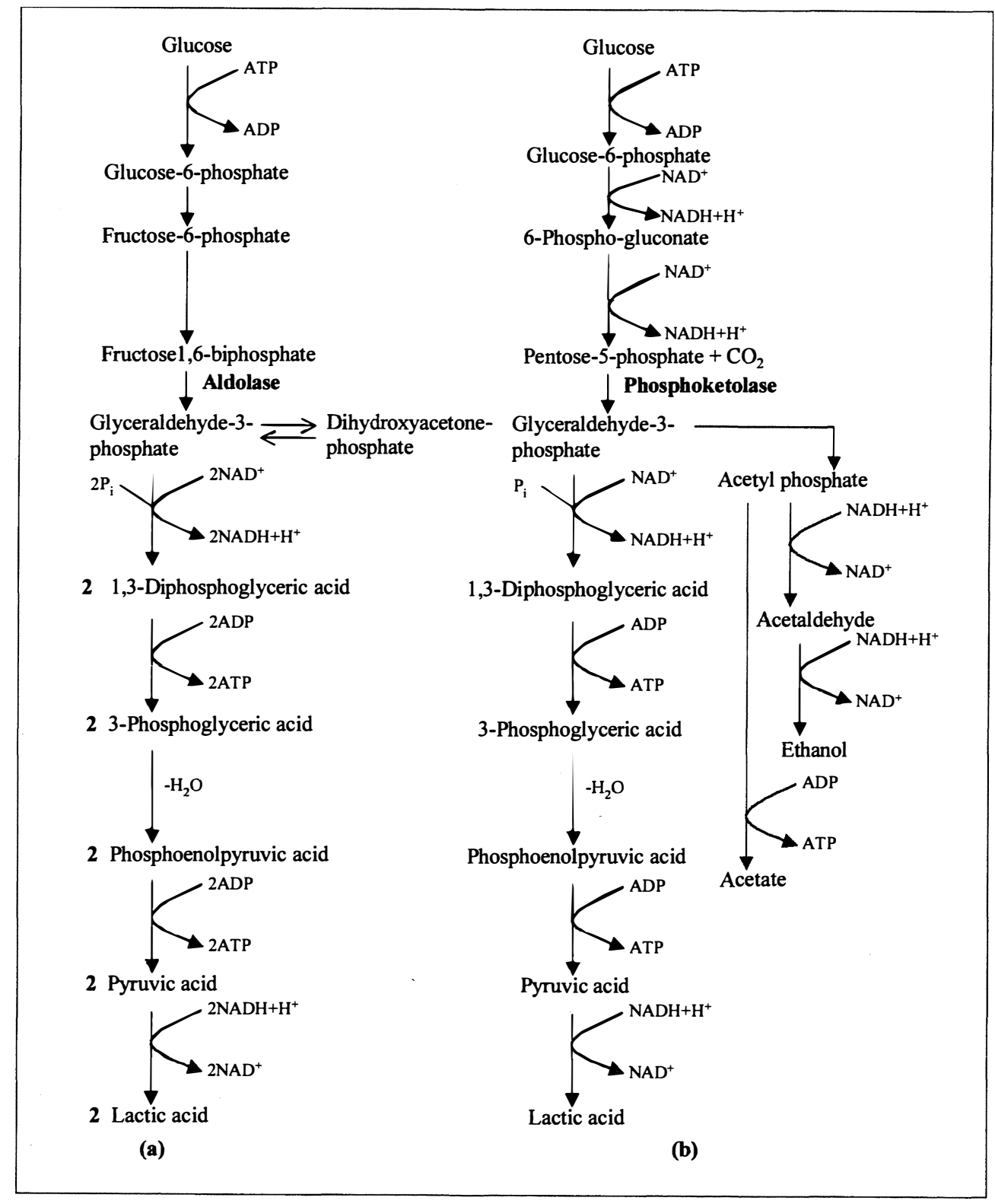

FIGURE 4

(a) Embden-Meyerhof-Parnas pathway (glycolysis) of homofermentative LAB and (b) 6-phosphogluconate pathway of heterofermentative LAB. 
acetate in combination with lactic acid (Sponholz, 1989; HenickKling, 1993). Associated wines do not have the typical vinegar flavour, but contain high amounts of D-lactic acid. This type of spoilage can occur during any stage of the winemaking process, when conditions favour the growth of LAB.

In addition to its sensorial effect on wine, acetic acid produced by LAB has been implicated in stuck or sluggish fermentations (Boulton et al., 1996; Edwards et al., 1999b). Huang et al. (1996) demonstrated that LAB can affect the rate of yeast-driven alcoholic fermentation. These bacteria were identified as $O$. oeni (Edwards et al., 1998a), and the novel ferocious lactobacilli as Lactobacillus kunkeei (Edwards et al., 1998b). L. kunkeei has the ability to grow to numbers of $10^{9} \mathrm{cfu} / \mathrm{ml}$ in the early stages of alcoholic fermentation, which is concomitant with the production of acetic acid at 4 to $5 \mathrm{~g} / \mathrm{L}$ (Edwards et al., 1999b). Acetic acid is known to inhibit the growth and fermentation of Saccharomyces, and will thus influence the rate at which the grape juice is converted to ethanol. L. kunkeei has been associated with wines to which no $\mathrm{SO}_{2}$ was added, the grape juice was left for several days before inoculation with yeast, and the initial must $\mathrm{pH}$ was above 3.5 (Boulton et al., 1996). Results obtained by Edwards et al. (1999b) showed that the production of acetic acid by L. kunkeei is not solely responsible for the inhibition of Saccharomyces and that further research is needed. Acid production problems caused by LAB can largely be eliminated if good winemaking practises are followed, using sensible amounts of $\mathrm{SO}_{2}$, inoculation of grape juice with the yeast directly after crushing and adjusting the pH to less than 3.5 (Edwards et al., 1999a).

\section{Re-fermentation}

This is also known as misplaced MLF, and can occur in bottled wine with a $\mathrm{pH}>3.5$ in the presence of $\mathrm{LAB}$ and nutrients (malate or residual sugars) that enhance growth. If secondary growth of $\mathrm{LAB}$ occurs in the wine, it will be deacidified and the $\mathrm{pH}$ will rise above 3.5. This problem can be corrected by the addition of tartaric acid (Boulton et al., 1996; Fugelsang, 1997); the spoilage can be controlled as above.

\section{Mannitol}

Mannitol is produced by heterofermentative lactobacilli, with the reduction of fructose or fructose-6-phospate (Sponholz, 1993; Boulton et al., 1996; Fugelsang, 1997). Mannitol itself is not the culprit; the problem is the accompanying production of acetic acid, D-lactic acid, propanol, butanol and diacetyl. The wine is perceived as viscous, sweetish and acetate-esterish in taste (Sponholz, 1993), and is mainly associated with dessert and berry wines.

\section{Ropiness}

Wines with an increase in viscosity and a slimy appearance are called "ropy". Viscosity is attributed to the production of extracellular polysaccharide, composed of D-glucan (Llaubères et al., 1990), and the genera Leuconostoc and Pediococcus have been implicated in ropiness (Lonvaud-Funel et al., 1993; Manca de Nadra \& Strasser de Saad, 1995; Fugelsang, 1997). The production of extracellular polysaccharides by Pediococcus damnosus and Pediococcus pentosaceus isolated from ropy wines was induced by ethanol, and this trait was plasmid mediated (Lonvaud-Funel et al., 1993; Manca de Nadra \& Strasser de Saad, 1995). Pediococci associated with ropiness differ from other pediococci in their resistance to ethanol, $\mathrm{SO}_{2}$ and $\mathrm{pH}$ (Lonvaud-Funel \& Joyeux, 1988), and the ropiness thus only occurs during alcoholic fermentation or after bottling when ethanol is present. Ropiness can be effectively controlled by lowering the $\mathrm{pH}$ to under 3.5.

\section{Mousiness}

Heterofermentative lactobacilli and the spoilage yeast Brettanomyces have been implicated in wine that is reminiscent of mouse urine or acetamide. The lactobacilli associated with this defect are Lactobacillus brevis, Lactobacillus cellobiosus (now synonymous with Lactobacillus fermentum) and Lactobacillus hilgardii (Heresztyn, 1986a; Sponholz, 1993; Fugelsang, 1997). As in Brettanomyces, the guilty substances are the ethyl amino acid (lysine) derivatives, 2-acetyl-1,4,5,6-tetra hydropyridine and its isomer, 2-acetyl-3,4,5,6-tetra hydropyridine (Heresztyn, 1986a, b; Boulton et al., 1996). Microbial production of these compounds and their propionyl analogues is dependent on ethanol or propanol, and are therefore associated with wine rather than grape juice (Heresztyn, 1986a).

\section{Organic acid utilisation}

Organic acids in wine, primarily citric, tartaric and sorbic acid, can be metabolised by certain LAB to affect the wine quality to a degree that the wine is considered spoiled.

Citric acid catabolism is linked to malic acid degradation or MLF (Martineau \& Henick-Kling, 1995; Saguir \& Manca de Nadra, 1996). Products produced during citrate metabolism are of sensorial importance to the winemaker, and when produced in elevated concentrations contribute negatively to the complexity of the wine (Fig. 5). The most important metabolite is diacetyl, which in wine is perceived as buttery, nutty and/or toasty (Martineau \& Henick-Kling, 1995; Nielsen \& Prahl, 1997). (Yeast can also produce diacetyl from citrate, but the levels are not objectionable). The increase in diacetyl above the threshold value $(>4 \mathrm{mg} / \mathrm{L})$ results from the growth of LAB after alcoholic fermentation and/or during MLF (Rankine et al., 1969; Sponholz, 1993; Nielsen \& Prahl, 1997; Fugelsang, 1997). The amount of diacetyl produced by the preferred malolactic starter culture, $O$. oeni, is relatively low when compared to the possible spoilage levels produced if lactobacilli or pediococci have grown in the wine after MLF.

Sorbic acid may be metabolised by certain $\mathrm{LAB}$, and the resulting defect in wine is known as "geranium tone", an off-odour typical of crushed geranium leaves. Sorbic acid is a short chain fatty acid that may be used as a chemical preservative to inhibit yeast growth (S. cerevisiae) in sweetened wines, but has no effect on LAB (E்dinger \& Splittstoesser, 1986; Zoecklein et al., 1995; Fugelsang, 1997). Certain LAB are able to reduce sorbic acid to sorbinol through hydrogenation. Thereafter, under wine conditions, it will isomerise to form the alcohol 3,5-hexadiene-2-ol (Fig. 6). This alcohol reacts with ethanol to form 2-ethoxyhexa3,5-diene, which is responsible for the "geranium tone" (Crowell \& Guymon, 1975; Sponholz, 1993; Fugelsang, 1997). This phenomenon has been observed only in oenococci, and not in lactobacilli and pediococci studied thus far (Radler, 1976; Edinger \& Splittstoesser, 1986). Care should thus be taken when adding sweeteners or treating wine with sorbic acid as preservative, since auto-oxidation can take place resulting in products such as 


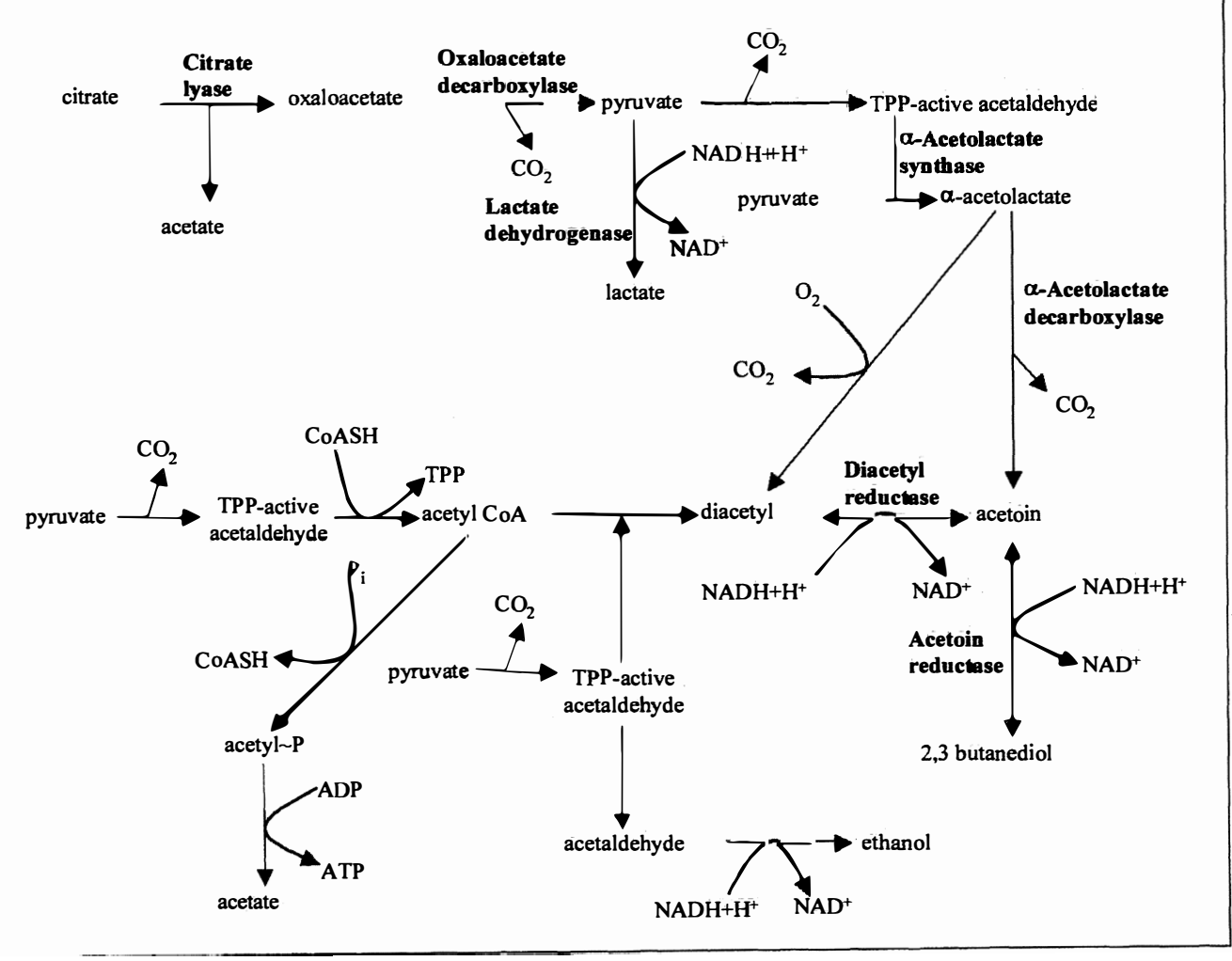

FIGURE 5

Metabolism of citric acid by LAB with the production of diacetyl

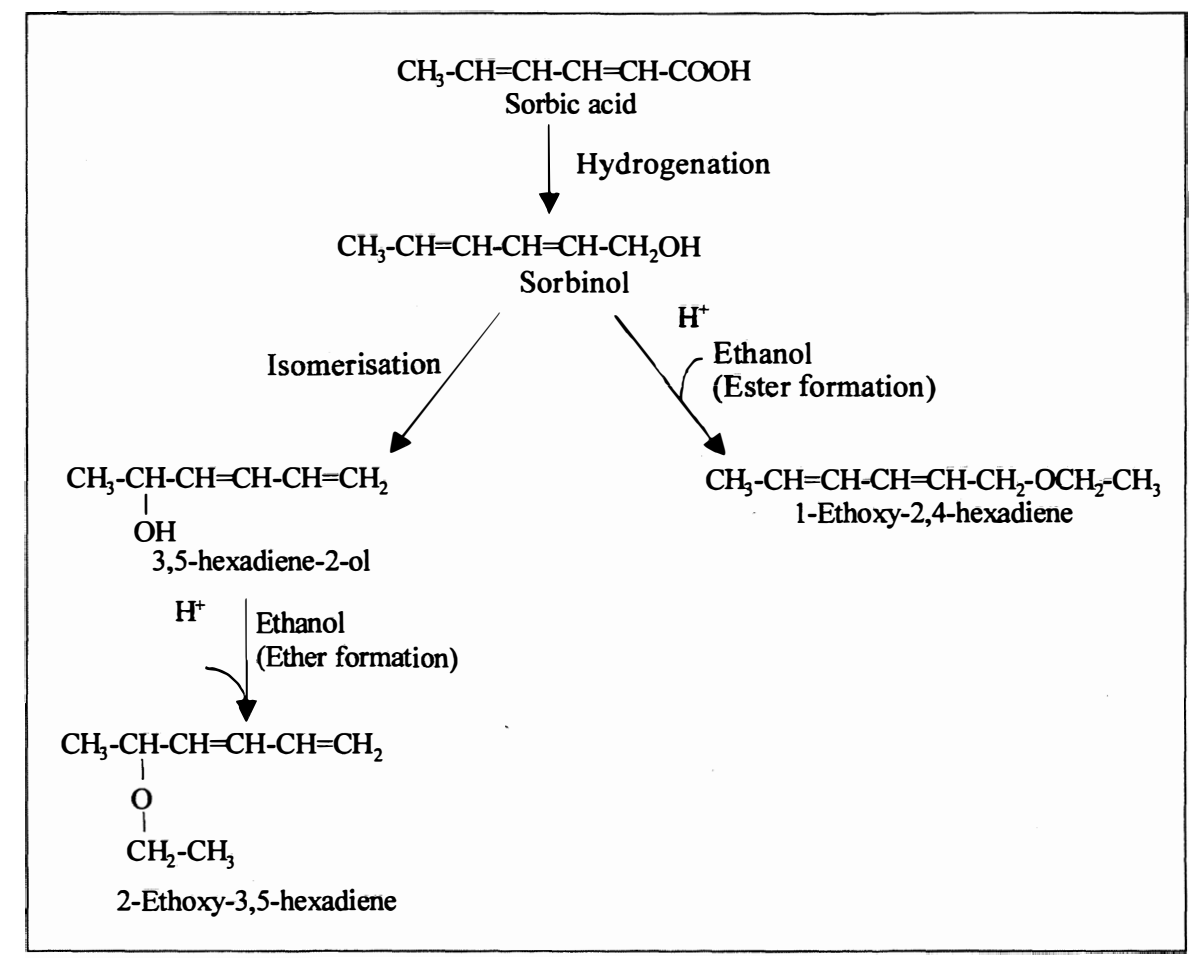

FIGURE 6

Utilisation of sorbic acid by LAB and the production of geranium tone. 


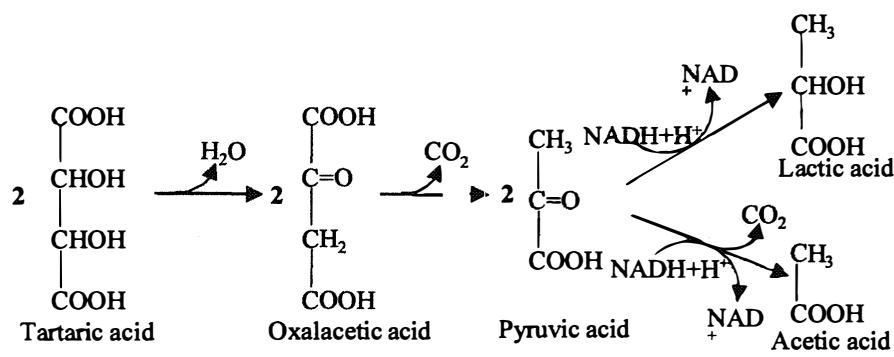

(a)
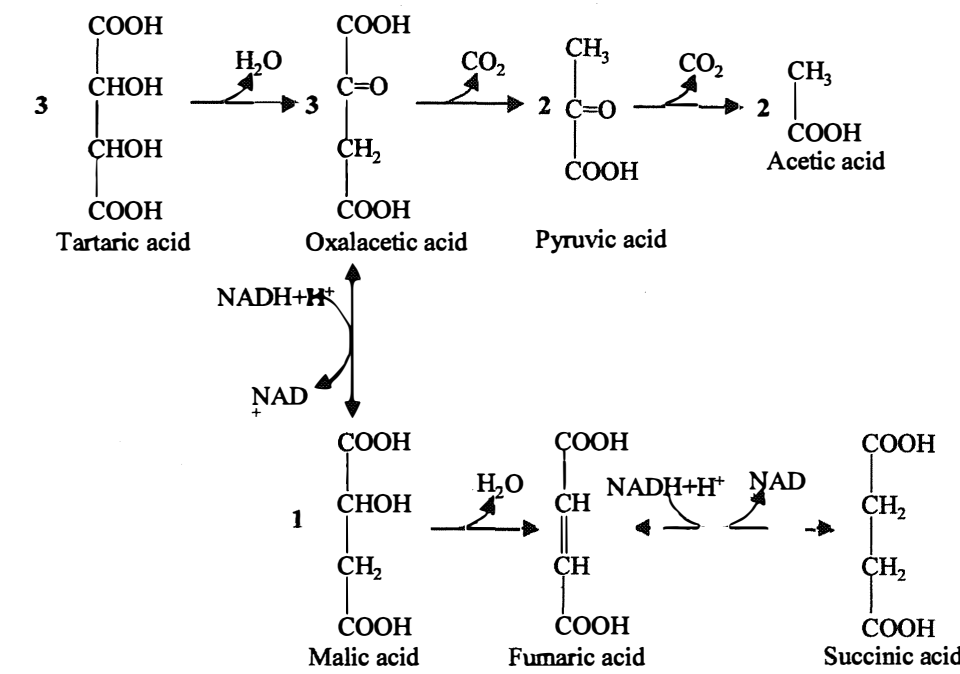

(b)

FIGURE 7

Degradation of tartaric acid by (a) L. plantarum and (b) L. brevis.

acrolein, crotonaldehyde and formic acid (Marx \& Sabalitschka, 1965).

Tartaric acid is regarded as microbiologically stable, but a few lactobacilli were discovered with the ability to degrade tartaric acid under wine conditions (Radler \& Yannissis, 1972; Wibowo et al., 1985). Wines susceptible to tartaric acid degradation have been seriously spoiled, with other faults also evident (Sponholz, 1993). Radler \& Yannissis (1972) implicated strains of Lactobacillus plantarum and L. brevis in the degradation of tartaric acid (Fig. 7). However, these two species are facultatively heterofermentative and obligately heterofermentative, respectively, and degrade this acid differently. Radler \& Yannissis (1972) have elucidated the mechanism of degradation; the key enzyme for both species is tartrate dehydratase, which converts tartaric acid to oxalacetic acid. L. plantarum has a simple metabolism when compared to L. brevis. L. plantarum reduces tartaric acid yielding lactic acid, acetic acid and $\mathrm{CO}_{2}$, whereas $L$. brevis yields succinic acid, acetic acid and $\mathrm{CO}_{2}$. Metabolising tartaric acid to yield acetic acid as end product might increase the volatile acidity of wine to levels that will render the wine unacceptable.

\section{Acrolein}

Acrolein is produced during bacterial degradation of glycerol and as a single component is not problematic. However, when it reacts with the phenolic groups of anthocyanins it produces wine with an unpleasant bitterness (Fig. 8). Pasteur associated this defect in red wines with rod-shaped bacteria and reduced levels of glycerol. (This problem is usually associated with red wines rather than white wines due to their higher phenolic content). Acrolein formation has been associated with species of the genera Lactobacillus, Leuconostoc, Oenococcus and Pediococcus, but it is definitely strain dependent (Kandler, 1983; Schütz \& Radler, 1984; Davis et al., 1988). Strains possessing a dehydratase enzyme convert glycerol into 3-hydroxypropionaldehyde (Sliniger et al., 1983; Boulton et al., 1996). The fate of 3-hydroxypropionaldehyde is dependent on the conditions prevailing in the wine: (i) spontaneous dehydration due to heat or storage under acidic conditions yielding acrolein; (ii) heterofermentative lactobacilli, such as L. brevis, assisting in maintaining the redox balance of the 6-phosphogluconate pathway by the production of 1,3-propandiol by a dehydrogenase enzyme (This will only occur in the presence of glucose); (iii) the aldehyde is oxidised to 3hydroxypropionic acid in the absence of glucose; (iv) acrolein, apart from its bitterness, can also be reduced to an allyl alcohol in the presence of NADH (Schütz \& Radler, 1984; Sponholz, 1993).

\section{Biogenic amines}

Biogenic amines and ethyl carbamate do not spoil wine with off- 


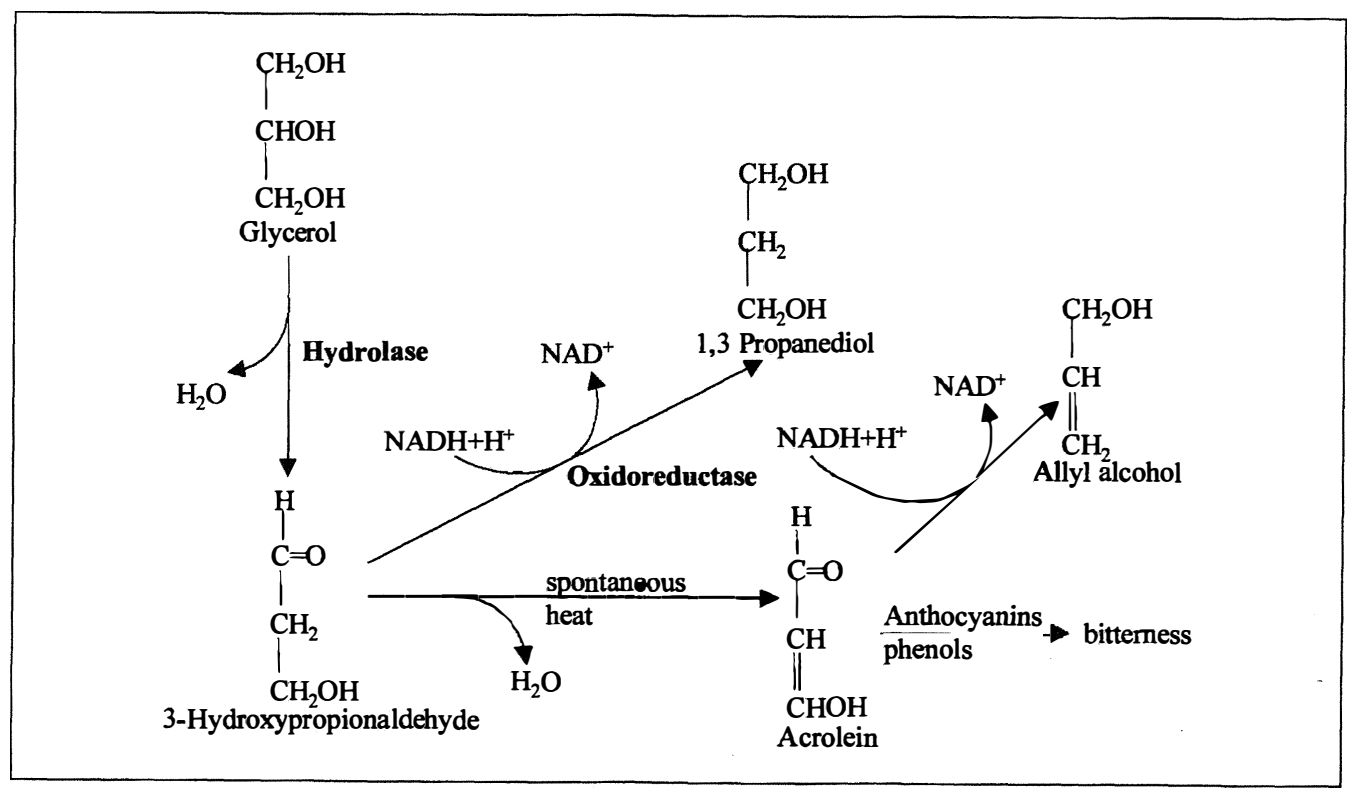

FIGURE 8

Production of acrolein and bitterness from glycerol degradation by L. brevis.

flavours or cosmetic problems, but pose health implications for the consumer in that the hygienic quality or wholesomeness of the wine can be affected.

The production of biogenic amines in wines through LAB should thus be considered an important criterion in the selection of starter cultures, and in noting the characteristics of the autochthonous microflora present in the wine environment. Considerable research has been conducted on the biogenic amine content of wine, but the techniques employed were generally semi-quantitative and very time consuming (Ough, 1971; RivasGonzalez et al., 1983; Zee et al., 1983; Cilliers \& van Wyk, 1985). Recent advances in analytical methods for the detection and quantification of biogenic amines have also raised questions about wines currently being produced.

Biogenic amines are produced by specific amino acid decarboxylases from their respective precursor amino acids (Fig. 9). These amines are low molecular weight organic bases with high biological activity. Histamine is the best studied biogenic amine and can cause headaches, hypotension and digestive problems, whereas tyramine and phenylethylamine are associated with migraines and hypertension if consumed in high concentrations (Soufleros et al., 1998). Concentrations normally prevailing in wine are not considered problematic, but Aerny (1982) indicated that ethanol and acetaldehyde might enhance the toxicity of these amines. Histamine, tyramine, putrescine, cadaverine and phenylethylamine are the most important biogenic amines under winemaking conditions (Zee et al., 1983; Lonvaud-Funel \& Joyeux, 1994). The formation of biogenic amines in wines is dependent on certain factors: (i) precursor amino acids present in the grape juice; (ii) presence of decarboxylase positive microorganisms; (iii) duration of alcoholic fermentation; (iv) level of sulphur dioxide; (v) $\mathrm{pH}$; and (vi) time of skin contact during fermentation (Vidal-Carou et al., 1990b).
The origin of biogenic amines in wines is controversial: some researchers believe that yeasts are responsible for their formation (Lafon-Lafourcade, 1975; Buteau et al., 1984), while others attribute their presence to a result of decarboxylating LAB (Delfini, 1989; Vidal-Carou et al., 1990a, b; Lonvaud-Funel \& Joyeux, 1994; Le Jeune et al., 1995; Coton et al., 1998; Soufleros et al., 1998). It was demonstrated that $O$. oeni, frequently associated with the initiation of MLF, has the ability to form histamine; it is therefore important to determine if malolactic starters are decarboxylase-positive, to reduce the risk of amine formation during vinification (Lonvaud-Funel \& Joyeux, 1994; Coton et al., 1998).

High levels of biogenic amines in wines correlate to certain wine compounds indicative of wine spoilage. These include higher alcohols, succinic acid, butyric acid, lactic acid, acetic acid, ethyl acetate, acetoin and diethyl succinate (Soufleros et al., 1998). Increases in these acids would increase the volatile acidity of the wine, which correlates with results obtained by VidalCarou et al. (1990b), viz. that wines with a higher VA contain higher levels of biogenic amines. The formation of these amines is greatest during MLF (Vidal-Carou et al., 1990b; Soufleros et al., 1998). Coton et al. (1998) also indicated that the histamine content of wines could increase during storage.

Although wines exceeding the legal physiological limit of biogenic amines are still relatively few (or unidentified), the seriousness of this problem should not be underestimated.

\section{Arginine metabolism}

Certain wine-associated LAB have the ability to utilise arginine; these include strains of $O$. oeni and heterofermentative LAB (e.g., L. brevis, L. buchneri, L. hilgardii). Homofermentative LAB (e.g., L. delbrueckii, L. plantarum) and pediococci do not catabolise arginine (Weiller \& Radler, 1976; Pilone et al., 1991; Edwards \& Jensen, 1992; Edwards et al., 1993; Liu et al., 1994, 


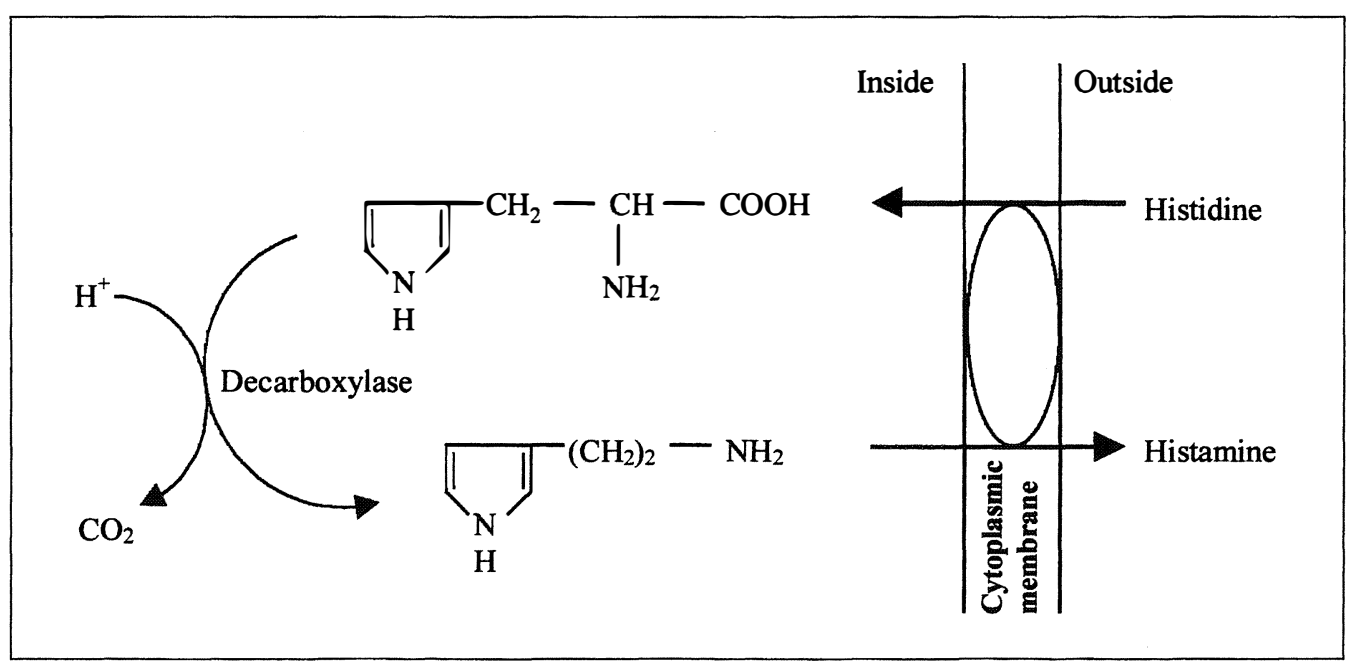

FIGURE 9

Production of biogenic amines by certain decarboxylating LAB with histamine as an example.

1995a, b; Liu \& Pilone, 1998). Arginine catabolism by LAB produces precursors for the formation of ethyl carbamate (urethane), a known human and animal carcinogen found in wine (Ough, 1976, 1993).

Arginine catabolism was first thought to involve an arginase and urease enzyme with the formation of ornithine and urea (Kuensch et al., 1974; Sponholz et al., 1991). However, Liu et al. (1996) concluded that the arginine deiminase pathway is active for the catabolism of arginine by wine $\mathrm{LAB}$, since no arginase and urease activity could be detected in the LAB wine strains capable of arginine degradation. The arginine deiminase (ADI) pathway involves three enzymes: arginine deiminase (ADI), ornithine transcarbamylase (OTC) and carbamate kinase (CK) (Fig. 10). The intermediates of the ADI pathway, citrulline and carbamyl phosphate, can react with ethanol to form ethyl carbamate (Ough et al., 1988a). The ethanolysis of citrulline occurs at elevated temperatures or at low to normal wine storage temperatures (Stevens \& Ough, 1993). Urea produced from arginine by wine yeasts is the major precursor for the formation of ethyl carbamate (Monteiro \& Bisson, 1991; Liu \& Pilone, 1998). Citrulline is excreted during the metabolism of arginine and this correlates to the formation of ethyl carbamate. Citrulline concentrations are at a maximum level when arginine concentrations are at their minimum (Liu et al., 1994). In the USA ethyl carbamate concentrations of $15 \mathrm{ng} / \mathrm{g}$ in table wines are the legal limit (Liu \& Pilone, 1998). The small amounts of citrulline excreted can increase the ethyl carbamate concentrations to objectionable levels.

The above suggests that spontaneous MLF should be discouraged, as the risk of elevated ethyl carbamate concentrations are increased when the characteristics of the indigenous wine LAB are unknown. Therefore, MLF starter cultures should be screened for the production of citrulline to minimise the formation of ethyl carbamate.

\section{SPOILAGE BY ACETIC ACID BACTERIA}

AAB belong to the family Acetobacteriaceae and are commonly known as the vinegar bacteria. AAB are Gram-negative, aerobic, catalase-positive microorganisms and can utilise glucose, with acetic acid as the end-product. According to Holt et al. (1994) there are microscopic variations among pure cultures and their cell morphology may range from spherical, club-shaped, elongated, swollen, curved rods to filamentous. This makes the preliminary identification of wine-related $\mathrm{AAB}$ with light microscopy difficult for the novice. The habitat of these bacteria is ubiquitous; they are found on flowers, fruit and vegetables, in wine and beer as spoilage microorganisms, and in vinegar as the primary fermenter (Drysdale \& Fleet, 1988; Swings, 1992; Fugelsang, 1997). The taxonomic position of AAB was not clearly defined until recently, with the application of modern taxonomic techniques such as numerical analysis of total soluble whole-cell protein patterns, fatty acid composition, plasmid profiles, distribution of respiratory quinones, DNA-DNA homology and rRNA hybridisation, (Yamada et al., 1981, 1984, 1997; Gosselé et al., 1983a, b; Yamada \& Kondo, 1984; Teuber et al., 1987; Mariette et al., 1991; Sievers et al., 1992, 1994, 1995; Sokollek et al., 1998). Results obtained with these techniques confirmed that Acetobacter and Gluconobacter are closely related and belong to one family.

These two AAB genera are of importance to the wine industry (Drysdale \& Fleet, 1988; Swings, 1992). They are linked by the fact that they can oxidise ethanol to acetic acid (a process called acetification), and are differentiated in that Acetobacter spp. can overoxidise acetic acid and lactic acid to $\mathrm{CO}_{2}$ and $\mathrm{H}_{2} \mathrm{O}$ via the tricarboxylic acid (TCA) cycle (Drysdale \& Fleet, 1989; Swings, 1992). The genus Gluconobacter is represented by three species Gluconobacter asaii, Gluconobacter frateurii and Gluconobacter oxydans, of which $G$. oxydans is important to the winemaking process (De Ley \& Swings, 1984; Holt et al., 1994). The genus Acetobacter is composed of seven species; four are important in winemaking: Acetobacter aceti, Acetobacter hansenii, Acetobacter liquefaciens and Acetobacter pasteurianus (De Ley et al., 1984; Swings, 1992; Holt et al., 1994) (Fig. 11).

For the most part, Acetobacter and Gluconobacter spp. lack the phosphofructokinase enzyme important for a functional Embden- 


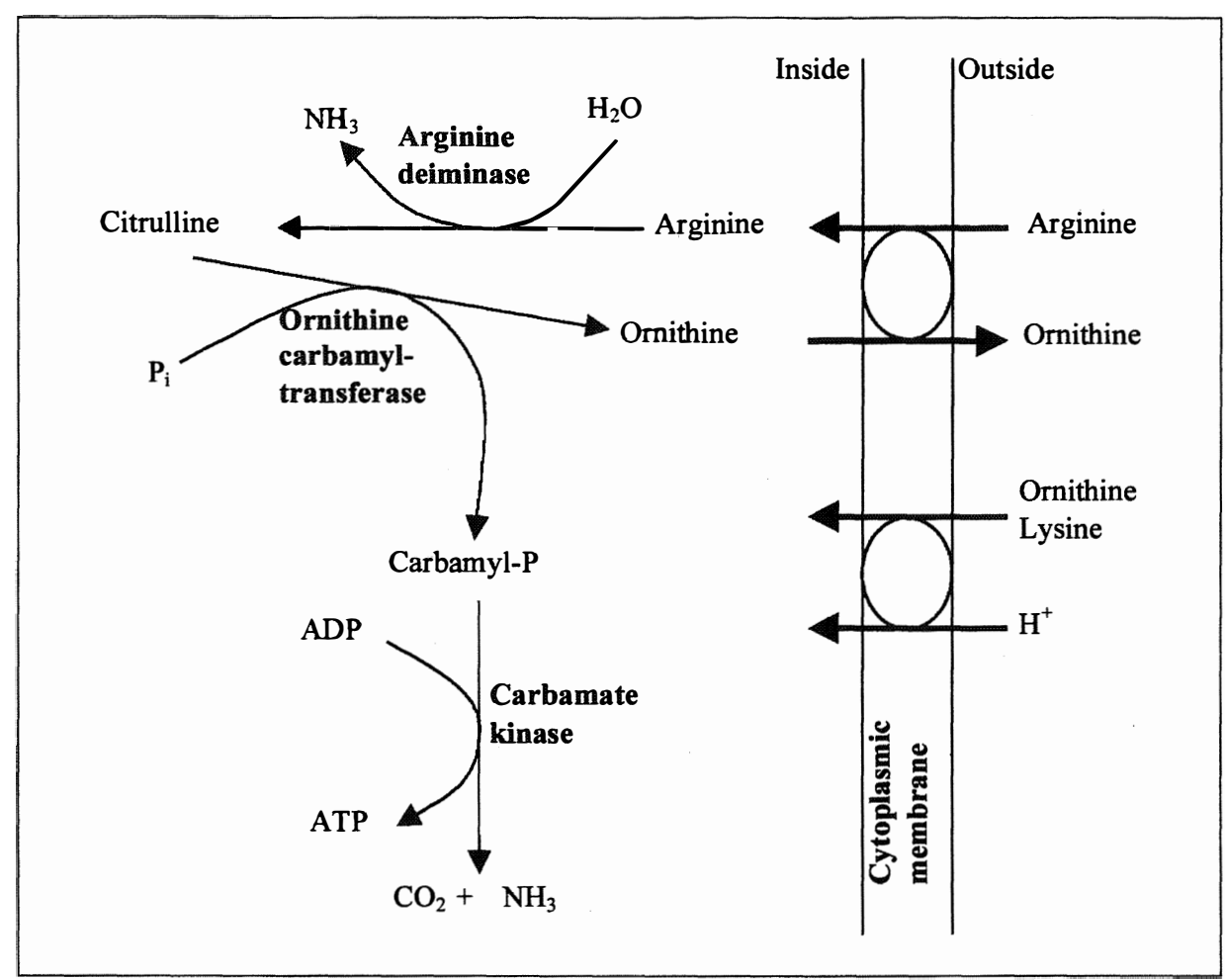

FIGURE 10

Arginine catabolism by LAB through the arginine deiminase pathway.

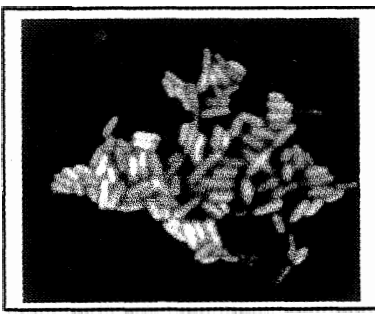

(a)

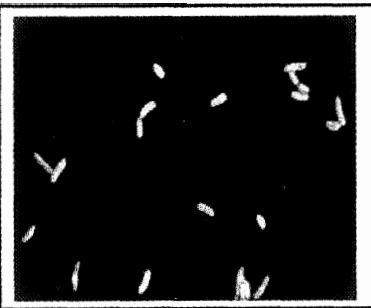

(c)

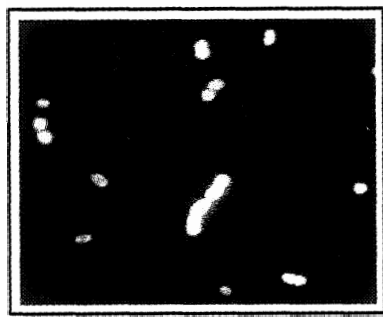

(e)

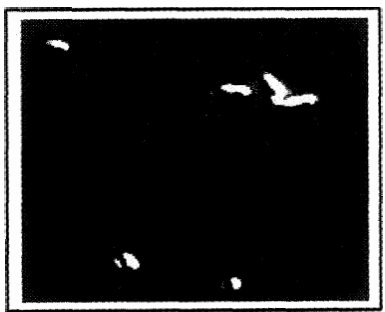

(b)

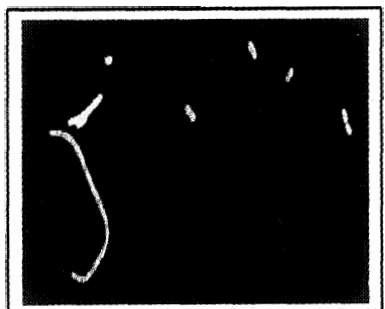

(d)

FIGURE 11

Photomicrographs of (a) Gluconobacter oxydans, (b) Acetobacter aceti, (c) Acetobacter hansenii, (d) Acetobacter liquefaciens, and (e) Acetobacter pasteurianus. 
Meyerhof-Parnas pathway (glycolysis), and are therefore unable to utilise hexoses via this pathway. Alternative pathways have evolved over the years; hexose and pentose sugars are oxidatively utilised through the hexose monophosphate pathway or by direct oxidation of hexose sugars to gluconate and ketogluconates, depending on the sugar concentration and $\mathrm{pH}$ prevailing in the must (Drysdale \& Fleet, 1989; Fugelsang, 1997).

The isolation of AAB from grapes, wineries, wines and oak barrels is well documented. Gluconobacter has a preference for sugar-rich environments where alcohol is present in low concentrations. This explains why Gluconobacter is normally isolated from grapes and must and disappears as soon as the alcoholic fermentation starts. Acetobacter spp. are more ethanol tolerant and may survive through the alcoholic fermentation to exert influence in the final product if care is not taken. Unspoiled, healthy grapes harbour low populations of AAB, generally $10^{2}-10^{3}$ cells/g, with $G$. oxydans being the dominant species (Grossman \& Becker, 1984; Joyeux et al., 1984a, b; Drysdale \& Fleet, 1988). Damaged, spoiled and Botrytis cinerea-infected grapes harbour $\mathrm{AAB}$ of $10^{6}$ cells/g, with A. aceti and A. pasteurianus dominant (Grossman \& Becker, 1984; Joyeux et al., 1984a, b; Drysdale \& Fleet, 1988). If care is not taken to control the levels of AAB, especially on spoiled grapes, the ethanol produced by the yeast may be converted to acetic acid, as the population present in the must correlates to that on the grapes. The grapes will have an acetic smell, with the must containing levels as high as $3.9 \mathrm{~g} / \mathrm{L}$ of acetic acid (Sponholz, 1993). It has been demonstrated that the exposure of wine to air, even the relatively small amounts that diffuse into the wine during pumping and transfer procedures, can stimulate their growth, with populations reaching as high as $10^{8}$ cells/ml (Joyeux et al., 1984b; Drysdale \& Fleet, 1989). AAB can also exert their effect in storage, where infected wines stored in wooden barrels may lead to the contamination of the barrels themselves (Wilker \& Dharmadhikari, 1997).

The distribution of Acetobacter spp. in wines is related to the country of origin. In Australia A. pasteurianus has been the dominant isolate, whereas in France and the USA, A. aceti was dominant (Vaughn, 1955; Joyeux et al., 1984b; Drysdale \& Fleet, $1985,1988)$. In a study undertaken at the Institute for Wine Biotechnology, the red wines of South Africa were dominated by A. pasteurianus and A. liquefaciens, but A. aceti and A. hansenii had the ability to survive in low numbers throughout fermentation (unpublished data).

\section{Volatile acidity}

Acetic acid is the major component in wine associated with volatile acidity. The legal limit for acetic acid in wine is 1.2$1.4 \mathrm{~g} / \mathrm{L}$, after which the wine becomes objectionable (Drysdale \& Fleet, 1988; Sponholz, 1993). However, acetic acid may also modify the perception of other important wine constituents. Tannins and fixed acids may be intensified. The esters of acetate, especially ethyl acetate, are major contributors to this defect in wine. Ethyl acetate is perceived as "fingernail polish" and has a detection level of $12.3 \mathrm{mg} / \mathrm{L}$; defective wines can contain levels of $150-200 \mathrm{mg} / \mathrm{L}$ (Boulton et al., 1996).

\section{Dihydroxyacetone}

The glycerol produced by yeast and moulds serves as carbon source for A. aceti and G. oxydans. These two species can convert glycerol into dihydroxyacetone under aerobic conditions (ketogenesis) (Eschenbruch \& Dittrich, 1986; Drysdale \& Fleet, 1988; Fugelsang, 1997). Dihydroxyacetone can affect the sensory quality of the wine with a sweet/etherish property. It can also react with proline and produce a "crust-like" aroma (Margalith, 1981; Drysdale \& Fleet, 1988; Boulton et al., 1996). Dihydroxyacetone can affect the antimicrobial activity in the wine, as it has the ability to bind $\mathrm{SO}_{2}$ (Eschenbruch \& Dittrich, 1986).

\section{Acetaldehyde}

Wines containing high amounts of AAB may contain significant amounts of acetaldehyde, an intermediate metabolite in the production of acetic acid from ethanol under low oxygen concentrations. Growth of Acetobacter may produce acetaldehyde at concentrations exceeding the threshold value of $100-120 \mathrm{mg} / \mathrm{L}$ (Drysdale \& Fleet, 1989). The descriptors of this defect in wine range from "classic" nutty and sherry-like to being reminiscent of overripe bruised apples (Zoecklein et al., 1995). Acetaldehyde binds $\mathrm{SO}_{2}$ and will thus affect the antimicrobial activity of the $\mathrm{SO}_{2}$ in wine. This combined compound may mask the odour of acetaldehyde (Fugelsang, 1997).

\section{Acetoin}

Strains of Acetobacter and Gluconobacter can oxidise lactic acid to acetoin under low-oxygen conditions. Acetoin has a characteristic aroma and flavour described as "butter-like", and the levels in wine have ranged from 3 to $31.8 \mathrm{mg} / \mathrm{L}$ (Drysdale \& Fleet, 1988; Boulton et al., 1996). In addition to affecting sensorial quality, the elevation of acetoin in wine by $\mathrm{AAB}$ may bind the free $\mathrm{SO}_{2}$ and eliminate its antimicrobial activity.

$\mathrm{AAB}$ have been neglected in the field of oenology, as they are classified as strict aerobes and were not thought to grow under the anaerobic conditions prevailing in wine. Recent research, however, has suggested that $\mathrm{AAB}$ can survive during the semi-anaerobic to anaerobic conditions that exist during alcoholic fermentation and in stored wine (Joyeux et al., 1984b; Drysdale \& Fleet, $1985,1989)$. Since significant populations of AAB may occur on grapes and survive through the fermentation process, they may therefore influence the growth of yeasts during alcoholic fermentation and alter the LAB population with a concomitant effect on MLF. It is therefore important that research be conducted on $A A B$ and their influence on wine quality.

\section{SPOILAGE BY ENDO-SPOREFORMING BACTERIA}

Rare incidences of Bacillus and Clostridium spp. have been reported in microbiological spoilage of wines. The genus Bacillus is comprised of aerobic Gram-positive, catalase-negative, endosporeforming rods. The natural habitat of this microorganism is primarily soil, and will thus secondarily occur in water, which would enable access of this organism into the wine environment. Clostridium is a Gram-positive, obligate anaerobic, endo-sporeforming rod.

\section{Acidity}

Gini \& Vaughn first reported on Bacillus spoilage in dessert wines in 1962. They isolated Bacillus subtilis, Bacillus circulans and Bacillus coagulans and demonstrated Koch's postulates by inoculating the different species into wine. They were able to grow to $10^{6}-10^{7}$ cells $/ \mathrm{ml}$, and the wine showed an increase in volatile and total acidity. Murrell \& Rankine (1979) attributed 
spoiled bottled brandy to the growth of Bacillus megaterium. Bacillus spp. isolated from wine corks have been shown to grow when inoculated into wine (Lee et al., 1984). More recent reports on Bacillus spoilage have been from wines produced in Eastern European countries (Bisson \& Kunkee, 1991; Boulton et al., 1996). The spoilage was cosmetic (sediment formation) and did not present any sensorial changes.

\section{Butyric acid taint}

Wines spoiled by Clostridium are even more infrequent than by Bacillus. They have been implicated in low acid, high $\mathrm{pH}(>4.0)$ wine (Sponholz, 1993). Growth of clostridia in wine yields nbutyric acid, acetic acid, $\mathrm{CO}_{2}$, hydrogen peroxide and, depending on the species, varying amounts of butanol, acetone and propanol (Sponholz, 1993). n-Butyric acid is perceived as a taint of rancidness.

Although incidences of Bacillus and Clostridium spoilage are rare, care should be taken, because under the right conditions they have the potential of significantly lowering wine quality.

\section{SPOILAGE BY MOULDS}

The infection of grapes by filamentous fungi (moulds) before harvest can be disastrous to the quality of wine if they are not controlled by the use of fungicides. Moulds found on grapes include species of the genera Alternaria, Aspergillus, Botrytis, Cladosporium, Mucor, Oidium, Penicillium, Plasmopara, Rhizopus and Uncinula (McGrew, 1982; Pearson, 1990; Donèche, 1993; Fugelsang, 1997; Fleet, 1998). Moulds can affect the wine quality in one of the following manners: (i) loss in juice yield, (ii) slippery nature of infected grapes prolongs the pressing process, (iii) alteration of the chemical composition of wine such as the production of gluconic acid, higher levels of glycerol, oxidation of phenolic compounds, (iv) secretes $\beta$-glucan that will negatively affect clarification, ( $v$ ) produce off-flavours (such as acetic acid), and (vi) stimulate the growth of spoilage yeasts and bacteria (Pearson \& Goheen, 1994). Moulds are sensitive to ethanol concentrations of $3 \%$, low $\mathrm{pH}, \mathrm{SO}_{2}$ and anaerobiosis, and though unable to survive in wine, they alter the chemical composition of the grape juice through the enzymes they secrete. These moulds can also grow on the surfaces of the wine cellar and on the wooden barrels used for ageing and give the wine a mouldy flavour. Fleet (1998) suggested evidence that moulds produce anti-yeast metabolites that might affect alcoholic and malolactic fermentations. Moulds can also produce mycotoxins, which are regarded as carcinogens, and thus a matter of great concern. The two genera of moulds associated with infected grapes that can produce these mycotoxins (such as aflatoxins, patulin and ochratoxin A) are Aspergillus and Penicillium (Scott et al., 1977; Boulton et al., 1996; Zimmerli \& Dick, 1996). It seems, however, that the winemaking/fermentation process inactivates these mycotoxins, as they have not been found in wine made from grapes containing them (Boulton et al., 1996).

\section{Cork taint}

Microbiological contamination of corks can affect the quality of the finished wine by producing off-flavours; corks are used as a substrate by microorganisms, leaching metabolites into the endproduct. The fungal genera associated with cork taint are Aspergillus, Cladosporium, Monilia, Paecilomyces, Penicillium and Trichoderma (Davis et al., 1981; Lefevebre et al., 1983; Lee
\& Simpson, 1993). Yeast and bacteria have been implicated as part of the natural cork flora, but they occur in numbers of $<10^{2}$ cfu/cork (Davis et al., 1982). Yeast species associated with cork are Candida, Cryptococcus, Rhodotorula, Saccharomyces and Sporodiobolus (Davis et al., 1982; Lee \& Simpson, 1993; Danesh et al., 1997). Bacterial species implicated in cork are Bacillus, Micrococcus, Streptococcus and Streptomyces (Davis et al., 1982; Lefevebre et al., 1983; Lee \& Simpson, 1993). Cork taint is perceived as a mouldy, earthy or musty off-flavour. The major compound responsible for the cork taint is 2,4,6-trichloroanisole (Lee \& Simpson, 1993). Amon et al. (1989) also implicated 1octen-3-ol, 1-octen-3-one, 2-methylisoborneol, geosmin and guaiacol as contributors to cork taint. For more detail on the structure and production of these compounds, see Lee \& Simpson (1993) for a comprehensive review on cork taint.

\section{PRESERVATION}

The presence of wine spoilage organisms in the cellar, wine and corks, as discussed above, illustrates the need for rigorous quality control to assure the microbiological stability of the winemaking process. Chemical preservatives are used in general to inhibit specific populations of microorganisms that endanger the quality of the end-product. The techniques used for food preservation have a long history, and include chilling, fermentation or acidification, addition of chemical preservatives, heat pasteurisation and sterilisation. This review will focus on chemical preservation. The techniques applied in the winemaking process to assure quality and microbiological safety include: (i) procedures that prevent access of microorganisms in the first instance; (ii) inactivation of unwanted microorganisms when the first step is unsuccessful; and (iii) procedures that slow or inhibit their growth in the product.

\section{Chemical preservation}

Preservatives used in the wine industry, such as sulphur dioxide, sorbic acid and benzoic acid, are most effective in their undissociated form, which is prevalent at a low $\mathrm{pH}$ (Zoecklein et al., 1995). Preservatives are more effective against stationary phase yeast and bacterial cultures than against actively growing cultures producing metabolites that can diminish the effectiveness of the preservative.

Sulphur dioxide: $\mathrm{SO}_{2}$ is one of the oldest compounds used in the food and beverage industries for its antioxidative and antimicrobial properties. The use of $\mathrm{SO}_{2}$ in winemaking dates back to the Egyptians, and later the Romans, who used burning sulphur fumes to clean their amphora and other wine vessels. In the centuries that followed $\mathrm{SO}_{2}$ became a widely used chemical preservative in the wine industry through the addition of sulphite or bisulphite to inhibit the growth of unwanted yeasts and bacteria.

Sulphite is present in three forms in an aqueous solution and the equilibria are $\mathrm{pH}$ dependent (Rose, 1987; Zoecklein et al., 1995). At low $\mathrm{pH}$ values sulphite exists mainly as molecular $\mathrm{SO}_{2}$, at intermediate $\mathrm{pH}$ values as bisulphite ions, and at high $\mathrm{pH}$ values as sulphite ions (Rose, 1987; Romano \& Suzzi, 1993). It has been demonstrated that only the molecular form of $\mathrm{SO}_{2}$ exerts the antimicrobial activity (Rose, 1987; Usseglio-Tomasset, 1992; Fugelsang, 1997). At wine $\mathrm{pH}$ values (3.0-4.0) the major proportion is bisulphite ions $(95 \%)$, with only $5 \%$ in the active molecular form (Romano \& Suzzi, 1993). 
$\mathrm{SO}_{2}$ can be robbed of its antimicrobial activity by binding to wine compounds, thereby rendering it inactive. In must and wine, the major $\mathrm{SO}_{2}$-binding compounds are acetaldehyde, anthocyanins, sugars, keto-acids (such as gluconic and pyruvic acid) and dihydroxyacetone (Usseglio-Tomasset, 1992; Romano \& Suzzi, 1993; Zoecklein et al., 1995; Fugelsang, 1997). Grapes spoiled by $B$. cinerea and AAB, for example, contain higher levels of these $\mathrm{SO}_{2}$ binding substances, which necessitates an adjustment to $\mathrm{SO}_{2}$ levels normally used.

The use of $\mathrm{SO}_{2}$ is a delicate process, as the concentration added to the different stages of vinification should be sufficient to inhibit the unwanted spoilage species, but not the yeasts conducting the alcoholic fermentation or the LAB responsible for malolactic fermentation. The wine yeast ( $S$. cerevisiae) is resistant to relatively high levels of $\mathrm{SO}_{2}$ as a result of constant exposure and possibly natural selection over centuries. Other wine yeasts such as $Z$. bailii and S. ludwigii are problematic, as mentioned previously, because of their very high level of $\mathrm{SO}_{2}$ resistance $(>3 \mathrm{mg} / \mathrm{L}$ molecular $\mathrm{SO}_{2}$ ) (Thomas \& Davenport, 1985).

Traditionally, $\mathrm{SO}_{2}$ is added to the grapes at the crusher, as one of the objectives is to inhibit or suppress the growth of nonSaccharomyces yeasts so that $S$. cerevisiae can proliferate and dominate the fermentation. There have been indications that the pattern of yeast growth in wineries where total $\mathrm{SO}_{2}$ levels of 50$100 \mathrm{mg} / \mathrm{L}$ are commonly added allows for the growth of nonSaccharomyces yeasts at the beginning of alcoholic fermentation (Heard \& Fleet, 1988; Fleet, 1990; Romano \& Suzzi, 1993).

$\mathrm{SO}_{2}$ is an effective antimicrobial agent against LAB associated with must and wine, and they are more sensitive than yeasts. LAB strains vary in their sensitivity to $\mathrm{SO}_{2}$; Lactobacillus and Pediococcus are more resistant than Oenococcus (Wibowo et al., 1985; Davis et al., 1988). Research indicates that free $\mathrm{SO}_{2}$ levels of $1-10 \mathrm{mg} / \mathrm{L}$ is sufficient to inhibit the growth of wine LAB (Wibowo et al., 1985). Britz and Tracey (1990) showed that lower $\mathrm{pH}$ and higher ethanol levels enhanced the inhibitory activity of $\mathrm{SO}_{2}$.

The point at which $\mathrm{SO}_{2}$ is added to inhibit LAB depends on the style of wine to be made. When the wine must undergo MLF, $\mathrm{SO}_{2}$ is added after MLF is completed. Davis et al. (1985) observed that total $\mathrm{SO}_{2}$ concentrations of $40-50 \mathrm{mg} / \mathrm{L}$ significantly retarded the growth of $O$. oeni and therefore the initiation of MLF. This will enable the undesirable $\mathrm{SO}_{2}$-tolerant Lactobacillus or Pediococcus spp. to conduct the MLF.

According to Amerine \& Kunkee (1968), the growth of AAB should be inhibited with the correct use of $\mathrm{SO}_{2}$. However, Joyeux et al. (1984b) found AAB in wines containing $20 \mathrm{mg} / \mathrm{L}$ molecular $\mathrm{SO}_{2}$. The growth of Acetobacter spp. in grape must was inhibited only at $\mathrm{SO}_{2}$ concentrations of $>100 \mathrm{mg} / \mathrm{L}$ (Joyeux et al., 1984b; Drysdale \& Fleet, 1985), which indicates that they can proliferate under vinification conditions used today (less $\mathrm{SO}_{2}$ ), and may explain their higher incidence in wine. Drysdale \& Fleet (1988) showed that $G$. oxydans is more sensitive to $\mathrm{SO}_{2}$ than A. aceti or A. pasteurianus. The role of $\mathrm{SO}_{2}$ against $\mathrm{AAB}$ should be studied in more detail to elucidate the mechanism and effectiveness of this antimicrobial compound.

Though the winemaking process relies on the judicious use of $\mathrm{SO}_{2}$ to ensure high quality and microbial stability in the end- product, there is a worldwide trend to reduce $\mathrm{SO}_{2}$ levels, as health risks and organoleptic changes are associated with its use. Discontinuing $\mathrm{SO}_{2}$ as an antimicrobial agent without an alternative would increase the risk of wine spoiled by yeasts and bacteria. It is therefore important to continue the search for alternatives to $\mathrm{SO}_{2}$ preservation to ensure a "clean and green" product that will comply with consumer demands.

Sorbic acid: Sorbic acid is a short chain unsaturated fatty acid generally used in the food and beverage industries as an antifungal agent. It is used in some countries in sweetened wines to inhibit re-fermentation by S. cerevisiae (Zoecklein et al., 1995; Fugelsang, 1997). The solubility of sorbic acid is improved by using its salt, potassium sorbate. Sorbic acid is not an effective inhibitor of LAB, AAB or yeasts such as Brettanomyces, Saccharomycodes and Zygosaccharomyces. For example, G. oxydans is resistant to $1000 \mathrm{mg} / \mathrm{L}$ of sorbic acid (Splittstoesser \& Churney, 1992). Sorbic acid can be utilised by certain LAB to produce geranium-like off-flavours and make the wine objectionable. Sorbic acid is most effective in its undissociated form; it acts by disrupting the cell membrane function. The effectiveness of sorbic acid is directly related to the wine $\mathrm{pH}$, alcohol levels, $\mathrm{SO}_{2}$ concentrations and numbers of spoilage yeasts (Zoecklein et al., 1995).

Fumaric acid: Fumaric acid is used in some countries to control the growth of LAB, but its application is limited due to fumarase activity of lactobacilli, pediococci and oenococci (Ough \& Kunkee, 1974). Wine yeasts also possess the fumarase enzyme, which converts fumaric acid to malic acid (Fugelsang, 1997).

Benzoic acid: Benzoic acid is used in wine coolers along with sorbic acid and $\mathrm{SO}_{2}$. It is not used in table wines (Zoecklein et al., 1995).

Dimethyldicarbonate (DMDC): The common name for this product is Velcorin. DMDC is lethal against yeasts and bacteria, and can be used as a sterilant in wine to ensure a controllable fermentation with the inoculated starter cultures. The mode of action is the denaturation of the fermentative pathway enzymes such as glyceraldehyde-3-phosphate dehydrogenase and alcohol dehydrogenase (Porter \& Ough, 1982). Higher alcohol and temperature levels act synergistically with DMDC to decrease the time needed for killing (Terrell et al., 1993). DMDC is hydrolysed to $\mathrm{CO}_{2}$ and methanol; a concern is that no activity is left to protect the bottled product.

\section{Biopreservatives}

Although the traditional preservatives outlined above are still widely used, there exists a growing demand from consumers for alternative methods to preserve products. Consumer preferences have shifted to products that are less heavily preserved, less processed, of higher quality, more natural and healthier. This trend renders the use of chemical preservatives less acceptable to consumers, and has led to the possible exploitation of natural antimicrobial compounds from plants, animals and microorganisms as biological preservatives.

Bacteriocins: Bacteriocin production is a characteristic typical of many LAB (Schillinger, 1990; Daeschel, 1993; Nettles \& Barefoot, 1993; De Vuyst \& Vandamme, 1994). Bacteriocins of LAB are ribosomally synthesised antimicrobial peptides that inhibit closely related bacteria by destabilising the function of the 
cytoplasmic membrane. The bacteriocin-producing strain resists its own bacteriocin by producing a highly specific immunity factor (Quadri et al., 1995). They fall into three classes, based on their primary structure, molecular mass and heat stability: (Class I) lantibiotics, which are small, heat-stable, containing lanthionine, e.g., nisin; (Class II) non-lantibiotics, which are small and heat stable, e.g., pediocin PA-1, leucocin B-Ta11a, and (Class III) large and heat labile, e.g., helveticin $\mathrm{J}$ (Nes et al., 1996). Bacteriocins of LAB have received considerable attention due to their potential application as natural preservatives. They may provide a valuable, additional and controllable tool for the inhibition of some deleterious wine-associated organisms.

Nisin is the only LAB bacteriocin with GRAS (Generally

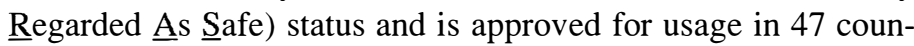
tries (Delves-Broughton, 1990). The possible use of bacteriocins, especially nisin, in winemaking has been evaluated (Radler, 1990a, b; Strasser de Saad et al., 1995), and the results obtained in these studies indicate that most LAB of importance in winemaking were inhibited by low concentrations of nisin. Wine yeasts were not affected, nor was the sensorial quality of the wine. However, $O$. oeni, responsible for MLF, was affected and nisin would not be applicable in wines having to undergo MLF. Daeschel et al. (1991) addressed this problem by developing nisin-resistant mutants of $O$. oeni, and these strains together with nisin produced a controlled, pure culture MLF. Although bacteriocins provide the winemaking community with a safe alternative to chemical preservation, their low cost efficiency is a limiting factor.

Bacteriolytic enzymes: Lysozyme is an enzyme with bactericidal properties, and is used as a preservative in the food industry; it is non-toxic and has GRAS status. Lysozyme is ubiquitously distributed in animals, plants, insects and phages; the commercial source is hen egg white (Tranter, 1994; Board, 1995). Lysozyme is defined as a 1,4- $B-N$-acetylmuramidase, which cleaves the $B$ 1,4-glycosidic bonds present in the peptidoglycan layer of the cell walls. Lysozyme exhibits both muramidase and chitinolytic activity (Fugelsang, 1997). The cell walls of Gram-positive bacteria have a thick peptidoglycan layer, while the Gram-negative cell walls have a thin peptidoglycan layer protected by an outer cell membrane. The antimicrobial action of lysozyme is thus limited to Gram-positive bacteria. Gram-negative bacteria can be sensitised for lysozyme by chelating agents such as EDTA, fusion of lysozyme to galactomannan, and modification of lysozyme by perillaldehyde (Fuglsang et al., 1995). Lysozyme has no effect on yeasts, is not affected by alcohol and is active in the $\mathrm{pH}$ range of the winemaking process (Fugelsang, 1997); its activity is, however, affected by its reaction with tannins, pigments and bentonite. Lysozyme can be used in winemaking for the inhibition or control of MLF, and microbial stabilisation after MLF (Amati.et al., 1996; Gerbaux et al., 1997, 1999). As lysozyme does not have antioxidative properties, it cannot replace $\mathrm{SO}_{2}$, but enables the use of reduced levels.

The OIV has recently approved the addition of lysozyme to the winemaking process, but the economic implications of using lysozyme are still a limiting factor.

Zymocins: Zymocins, killer toxins in yeasts, were first reported by Bevan \& Makower in 1963. Zymocins are produced by many yeast genera and are lethal to sensitive yeasts. They are proteina- ceous (proteins or glycoproteins), narrow spectrum antifungal compounds, which kill closely related species by depleting the proton motive force of the cell membrane. The killer strain is immune to its own toxin (Montville \& Kaiser, 1993; Shimizu, 1993; Dillon \& Cook, 1994). Montville \& Kaiser (1993) regard the yeast-produced zymocins as equivalent to the bacterially-produced bacteriocins.

Zymocidal yeasts include the genera Candida, Cryptococcus, Debaryomyces, Hanseniaspora, Kloeckera, Kluyveromyces, Pichia, Rhodotorula and Saccharomyces (Shimizu, 1993). They have been isolated from all stages of the winemaking process, from the grapes to the wines. Zymocidal strains can influence the winemaking process by delaying the start of fermentation, causing sluggish or stuck fermentation, increasing levels of acetaldehyde, acetic and lactic acid, and causing off-flavours (Benda, 1985; van Vuuren \& Wingfield, 1986). The zymocins of $S$. cerevisiae are generally active against $S$. cerevisiae, while the nonSaccharomyces yeasts producing zymocins have a broader spectrum of activity. S. cerevisiae killer strains therefore have the ability to dominate $S$. cerevisiae sensitive strains during vinification (Heard \& Fleet, 1987). The zymocins' stability and effectiveness is affected by $\mathrm{pH}$, ethanol levels, $\mathrm{SO}_{2}$ concentrations and binding with tannins and fining material (Radler \& Schmitt, 1987; Heard \& Fleet, 1987; Shimizu, 1993). The activity of zymocins is also highly influenced by the ratio of killer to sensitive cells at the onset of fermentation (Heard \& Fleet, 1987; Petering et al., 1991).

Killer yeasts have been classified into 11 groups $\left(\mathrm{K}_{1}-\mathrm{K}_{11}\right)$ on the basis of their toxin characteristics. The genetic determinants of zymocins are dsRNA plasmids, linear DNA plasmids and chromosome location (Shimizu, 1993). S. cerevisiae have three wellcharacterised zymocins, $\mathrm{K}_{1}, \mathrm{~K}_{2}$ and $\mathrm{K}_{28}$, of which the latter two are normally associated with winemaking, due to their activity at low $\mathrm{pH}$. Zymocins produced by killer $S$. cerevisiae strains have been used as biological control agents to suppress unwanted yeasts, but under oenological conditions this still remains uncertain. Zymocins were introduced to sensitive and killer wine yeasts by mating or recombinant DNA technology (Boone et al., 1990; Shimizu, 1993), but even a double killer $\left(\mathrm{K}_{1} / \mathrm{K}_{2}\right)$ S. cerevisiae was limited mainly to $S$. cerevisiae in its anti-yeast activity. It is therefore important to screen the non-Saccharomyces yeasts for zymocins with a broader activity spectrum and better adaptation to wine conditions, and to identify the encoding genes for introduction into $S$. cerevisiae wine yeasts.

\section{Development of wine yeast strains with antimicrobial activity}

Wine yeasts engineered for specific traits such as fermentation and processing efficiency, improved sensorial quality and increased wholesomeness have been researched and reviewed by Snow (1983) and Pretorius (1999, 2000). The use of recombinant DNA technology to transfer the genes encoding for antimicrobial enzymes and peptides to $S$. cerevisiae is well worth exploiting (Fig. 12). This would enable the winemaker to reduce the levels of chemical preservatives, if wine yeasts have the ability to secrete these novel biological preservatives during fermentation. The addition of engineered antimicrobial compounds is not yet cost-effective, however, and may be regarded as "unnatural" by purists. 


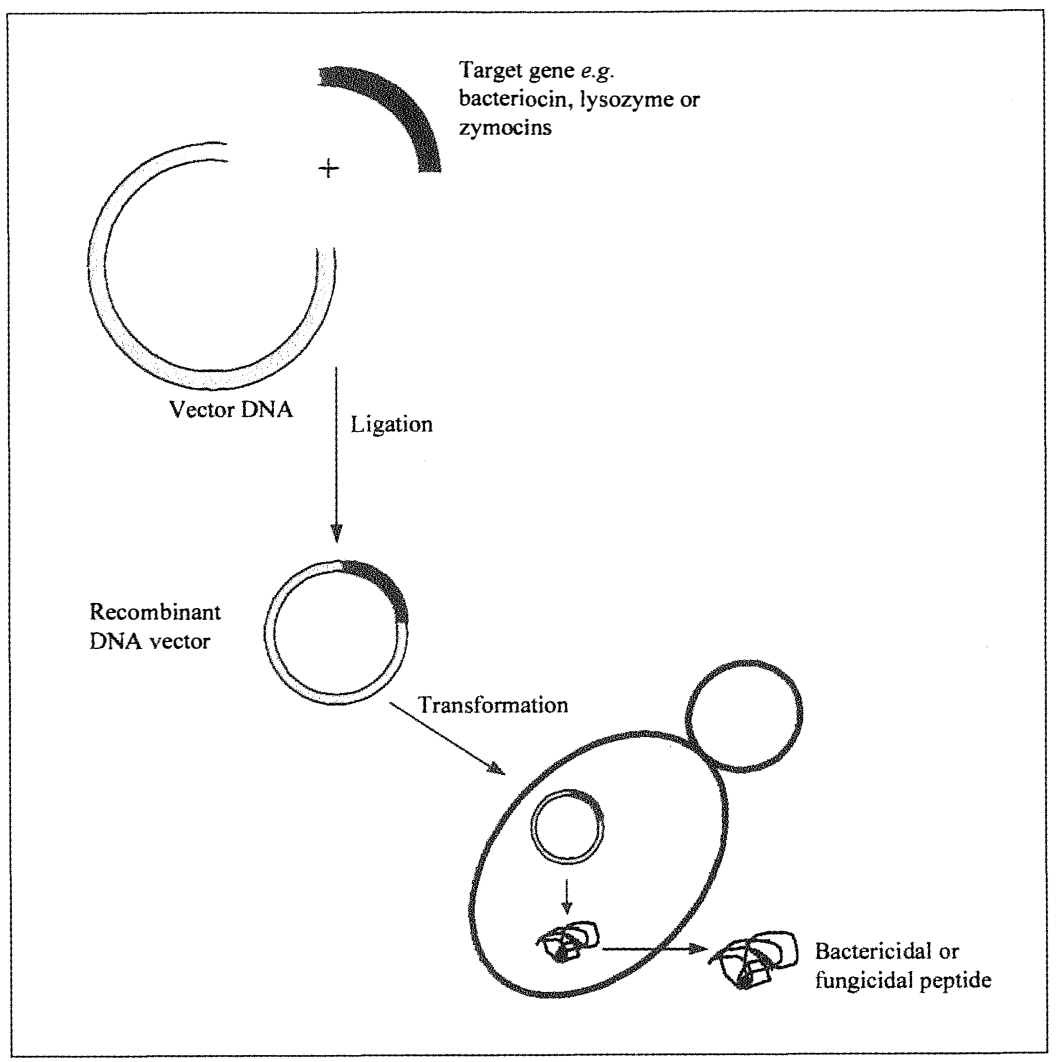

FIGURE 12

Engineering bactericidal/fungicidal $S$. cerevisiae strains as an altemative to chemical preservation.

We have investigated the possibility of developing bactericidal S. cerevisiae strains to control spoilage LAB during wine fermentation, through the cloning and expression of bacteriocin genes in yeasts. The bacteriocins of interest were pediocin PA-1 from Pediococcus acidilactici PAC 1.0 and leucocin B-Ta11a from Leuconostoc carnosum Ta11a (Gonzalez \& Kunka, 1987; Felix et al., 1994). The pediocin operon of P. acidilactici PAC 1.0 consists of pedA (encoding a 62 amino acid precursor of pediocin PA-1), pedB (encoding an immunity factor), pedC (transport protein) and pedD (precursor processing enzyme) (Marugg et al., 1992; Venema et al., 1995). The leucocin operon consists of only two genes, lcaB (encoding a 61 amino acid precursor of leucocin B-Ta11a) and $l c a B_{l}$ (encoding a 113 amino acid immunity factor) (Felix et al., 1994; Papathanasopoulos et al., 1997). Both the structural pedA gene and $l c a B$ gene were cloned into a multicopy expression vector containing the yeast $A D H I$-alcoholdehydrogenase gene promoter and terminator, and the yeast mating pheromone $\propto$-factor $(M F \propto 1)$ signal peptide. The different plasmid constructs were introduced into laboratory strains of S. cerevisiae. Stable pediocin and leucocin transcripts were produced in the yeasts and these transcripts were translated into functional proteins and secreted from the yeast cells (Schoeman et al., 1999; Du Toit et al., 1999).

The results confirmed our hypothesis that it is possible to create bactericidal wine yeast strains, but levels of production will have to be optimised. Although the use of $\mathrm{SO}_{2}$ cannot be eliminated, the levels can be greatly reduced when used in conjunction with bacteriocin-producing wine yeast strains.

The lysozyme-encoding gene has been successfully expressed in S. cerevisiae (Ibrahim et al., 1992, 1994; Nakamura et al., 1993; Kato et al., 1994; Arima et al., 1997; Hashimoto et al., 1998). The addition of a hydrophobic pentapeptide to the C-terminus of lysozyme changed the bactericidal action of the fusionlysozyme to include Gram-negative bacteria (Ibrahim et al., 1992, 1994; Arima et al., 1997). Research is currently also being conducted in our laboratory to express the lysozyme and fusionlysozyme genes in wine yeasts. This would enable wine yeasts to effectively combat the Gram-positive LAB and Gram-negative $\mathrm{AAB}$ wine spoilage bacteria.

\section{CONCLUSIONS}

Considerable progress has been made over the last decade in understanding the roles that yeasts, bacteria, moulds and viruses play in the winemaking process. Crucial questions remain: What can or should be done to control them? What species and strains grow at the various stages of the process? What substances are produced? These and many others need further attention. The development of molecular biology techniques, such as DNA probes, will be a helpful tool in identifying species and strains and following the progress of populations during the winemaking process. These probes can also be used to assess the risks of spoilage when certain species are present during vinification. Due to the vast biodiversity present on the grape berries and the natural populations occurring in grape juice, the selection of novel strains that do not possess undesirable characteristics should 
receive direct and intensive attention in the field of wine microbiology.

The challenge to the wine industry in the next few years will be finding alternatives to chemical preservation. Winemakers and researchers are looking at antimicrobial peptides and bacteriolytic enzymes; the compounds of interest are bacteriocins, zymocins and lysozyme. Preliminary results have indicated their potential usefulness, but the use of these bio-preservatives in wine production is largely dependent on their cost-effectiveness. Different combinations of these antimicrobial/antifungal peptides and enzymes will broaden the spectrum of inhibition. The problem of cost-effectiveness can be overcome by exploiting molecular yeast genetics to tailor wine yeasts with an arsenal of natural products that will satisfy the demands of both winemakers and consumers.

\section{LITERATURE CITED}

AERNY, J., 1982. L'histamine. Présence dans les denrées alimentaires et dans le vin en particulier. Revue Suisse Viticulture Arboriculture Horticulture 14, 7-13. AMATI, A., CHINNICI, F., PIVA, A., ARFELli, G. \& RIPONI, C., 1996. Influence of enological operations on lysozyme activity in winemaking. WeinWissenschaft 51, 59-62.

AMERINE, M.A. \& KUNKEE, R.E., 1968. Microbiology of winemaking. Ann. Rev. Microbiol. 22, 323-358.

AMON, J.M., VANDEPEER, J.M. \& SIMPSON, R.F., 1989. Compounds responsible for cork taint in wine. Austr. N.Z. Wine Ind. J. 2, 35-37.

ARIMA, H., IBRAHIM, H.R., KINOSHITA, T. \& KATO, A., 1997. Bactericidal action of lysozymes attached with various sizes of hydrophobic peptides to the Cterminal using genetic modification. FEBS Lett. 415, 114-118.

BENDA, I., 1985. Yeasts in winemaking-investigating so-called killer yeasts during fermentation. Der Deutscher Weinbau 40, 1166-1171.

BENDA, I. \& SCHMITT, A., 1969. Untersuchungen zum Säureabbau im Most durch verschiedene Hefestämme aus der Gattung Schizosaccharomyces. Weinberg und Keller 16, 71-83.

BEVAN, E.A. \& MAKOWER, M., 1963. The physiological basis of the killer character in yeasts. In: GEERTS, S.J. (ed). In: Proceedings of the $11^{\text {th }}$ International Congress of Genetics. pp. 202-203.

BISSON, L.F. \& KUNKEE, R.E., 1991. Microbial interaction during wine production. In: ZEIKUS, G. \& JOHNSON, E.A. (eds). Mixed Cultures in Biotechnology. McGraw-Hill, New York. pp. 37-68.

BOARD, R.G., 1995. Natural antimicrobials from animals. In: GOULD, G.W. (ed). New Methods of Food Preservation. Blackie Academic \& Professional, Glasgow. pp. 40-57.

BOONE, C., SDICU, A.-M., WAGNER, J., DEGRÉ, R., SANCHEZ, C. \& BUSSEY, H., 1990. Integration of the yeast K1 killer toxin gene into the genome of marked wine yeasts and its effect on vinification. Am. J. Enol. Vitic. 41, 37-42. BOULTON, R.B., SINGLETON, V.L., BISSON, L.F. \& KUNKEE, R.E., 1996. Principles and Practices of Winemaking. Chapman \& Hall, New York.

BRITZ, T.J. \& TRACEY, R.P., 1990. The combination effect of $\mathrm{pH}, \mathrm{SO}_{2}$, ethanol and temperature on the growth of Leuconostoc oenos. J. Appl. Bacteriol. 68, 2331.

BUTEAU, C., DUITSCHAVER, C.L. \& ASHTON, G.C., 1984. A study of biogenesis of amines in a Villard noir wine. Am. J. Enol. Vitic. 35, 228-236.

CHATONNET, P., DUBOURDIEU, D. \& BOIDRON, J.N., 1995. The influence of Brettanomyces/Dekkera sp. yeasts and lactic acid bacteria on the ethyl phenol content of red wines. Am. J. Enol. Vitic. 46, 463-468.

CHATONNET, P., DUBOURDIEU, D., BOIDRON, J.N. \& PONS, M., 1992. The origin of ethylphenols in wines. J. Sci. Food Agric. 60, 191-202.

CILLIERS, J.D. \& VAN WYK, C.J., 1985. Histamine and tyramine content of South African wine. S. Afr. J. Enol. Vitic. 6, 35-40.

COTON, E., ROLLAN, G., BERTRAND, A. \& LONVAUD-FUNEL, A., 1998. Histamine-producing lactic acid bacteria in wines: Early detection, frequency, and distribution. Am. J. Enol. Vitic. 42, 199-204.

CROWELL, E.A. \& GUYMON, I.F., 1975. Wine constituents arising from sorbic acid addition and identification of 2-ethoxyhexa-3,5- diene as a source of geranium-like off-odor. Am. J. Enol. Vitic. 26, 97-102.
DAESCHEL, M.A., 1993. Applications and interactions of bacteriocins from lactic acid bacteria in food and beverages. In: HOOVER, D.G. \& STEENSON, L.R. (eds). Bacteriocins of Lactic Acid Bacteria. Academic Press, London. pp. 63-91. DAESCHEL, M.A., JUNG, D-S. \& WATSON, B.T., 1991. Controlling wine malolactic fermentation with nisin and nisin-resistant strains of Leuconostoc oenos. Appl. Environ. Microbiol. 57, 601-603.

DANESH, P., VELEZ CALDAS, F.M., FIGUEIREDO MARQUES, J.J. \& ROMO, M.V., 1997. Mycobiota in Portuguese 'normal' and 'green' cork throughout the manufacturing process of stoppers. J. Appl. Microbiol. 82, 689-694.

DAVIS, C.R., FLEET, G.H. \& LEE, T.H., 1981. The microflora of wine corks. Aust. Grapegrower Winemaker 208, 42-44.

DAVIS, C.R., FLEET, G.H. \& LEE, T.H., 1982. Inactivation of wine cork microflora by a commercial sulfur dioxide treatment. Am. J. Enol. Vitic. 33, 124127.

DAVIS, C.R., WIBOWO, D., ESCHENBRUCH, R., LEE, T.H. \& FLEET, G.H., 1985. Practical implications of malolactic fermentation: A review. Am. J. Enol. Vitic. 36, 290-301.

DAVIS, C.R., WIBOWO, D., FLEET, G.H. \& LEE, T.H., 1988. Properties of wine lactic acid bacteria: Their potential enological significance. Am. J. Enol. Vitic. 39, 137-142.

DE LEY, J. \& SWINGS, J., 1984. Genus II. Gluconobacter. In: KRIEG, N.R. \& HOLT, J.G. (eds). Bergey's Manual of Systematic Bacteriology, vol. 1. The Williams \& Wilkens Co., Baltimore, MD. pp. 275-278.

DE LEY, J., SWINGS, J. \& GOSSELÉ, F., 1984. Genus I. Acetobacter. In: KRIEG, N.R. \& HOLT, J.G. (eds). Bergey's Manual of Systematic Bacteriology, vol. 1. The Williams \& Wilkens Co., Baltimore, MD. pp. 268-274.

DE REVEL, G., BELA CAPELA, A. \& HOGG, T., 1994. A pre-spoilage marker for bacterial activity in fortified wine, conversion of L-malic acid to L-lactic acid. Lett. Appl. Microbiol. 18, 329-332.

DE VUYST, L. \& VANDAMME, E.J., 1994. Bacteriocins of lactic acid bacteria. Chapman \& Hall, London.

DELFINI, C., 1989. Ability of wine malolactic bacteria to produce histamine. Sci. Aliment. 9, 413-416.

DELVES-BROUGHTON, J., 1990. Nisin and its uses. Food Technol. 44, 100117.

DICKS, L.M.T. \& VAN VUUREN, H.J.J., 1988. Identification and physiological characteristics of heterofermentative strains of Lactobacillus from South African red wines. J. Appl. Bacteriol. 64, 505-513.

DICKS, L.M.T., DELLAGLIO, F. \& COLLINS, M.D., 1995. Proposal to reclassify Leuconostoc oenos as Oenococcus oeni [corrig.] gen. nov., comb. nov. Int. J. Syst. Bacteriol. 45, 395-397.

DILLON, V.M. \& COOK, P.E., 1994. Biocontrol of undesirable microorganisms in food. In: DILLON, V.M. \& BOARD, R.G. (eds). Natural Antimicrobial Systems and Food Preservation. CAB International, Oxon. pp. 255-296.

DONÈCHE, B.J., 1993. Botrytized wines. In: FLEET, G.H. (ed). Wine Microbiology and Biotechnology. Harwood Academic Publishers, Chur. pp. 327353.

DRYSDALE, G.S. \& FLEET, G.H., 1985. Acetic acid bacteria in some Australian wines. Food Technol. Austr. 37, 17-20.

DRYSDALE, G.S. \& FLEET, G.H., 1988. Acetic acid bacteria in winemaking: A review. Am. J. Enol. Vitic. 39, 143-154.

DRYSDALE, G.S. \& FLEET, G.H., 1989. The growth and survival of acetic acid bacteria in wines at different concentrations of oxygen. Am. J. Enol. Vitic. 40, 99105 .

DU TOIT, M., SCHOEMAN, H., VIVIER, M.A., DICKS, L.M.T., HASTINGS, J.W. \& PRETORIUS, I.S., 1999. A yeast with antimicrobial activity as possible alternative to chemical preservatives. In: TUIJTELAARS, A.C.J., SAMSON, R.A., ROMBOUTS, F.M. \& NOTERMANS, S. (eds). Food Microbiology and Food Safety into the Next Millennium. Proceedings of the $17^{\text {th }}$ International Conference of the ICFMH. Ponsen \& Looyen, Wageningen. pp. 319-322.

EDINGER, W.D. \& SPLITTSTOESSER, D.F., 1986. Production by lactic acid bacteria of sorbinol alcohol, the precursor of the geranium odor compound. Am. J. Enol. Vitic. 37, 34-38.

EDWARDS, C.G. \& JENSEN, K.A., 1992. Occurrence and characterization of lactic acid bacteria from Washington state wines: Pediococcus spp. Am. J. Enol. Vitic. 43, 233-238.

EDWARDS, C.G., HAAG, K.M. \& COLLINS, M.D., 1998a. Identification and characterization of two lactic acid bacteria associated with sluggish/stuck fermentations. Am. J. Enol. Vitic. 49, 445-448. 
EDWARDS, C.G., HAAG, K.M., COLLINS, M.D., HUTSON, R.A. \& HUANG, Y.C., 1998b. Lactobacillus kunkeei sp. nov.: Spoilage organism associated with grape juice fermentations. J. Appl. Microbiol. 84, 698-702.

EDWARDS, C.G., HAAG, K.M., SEMON, M.J., RODRIGUEZ, A.V. \& MILLS, J.M., 1999a. Evaluation of processing methods to control the growth of Lactobacillus kunkeei, a micro-organism implicated in sluggish alcoholic fermentations of grape musts. S. Afr. J. Enol. Vitic. 20, 11-18.

EDWARDS, C.G., REYNOLDS, A.G., RODRIGUEZ, A.V., SEMON, M.J. \& MILLS, J.M., 1999b. Implication of acetic acid in the induction of slow/stuck grape juice fermentations and inhibition of yeast by Lactobacillus sp. Am. J. Enol. Vitic. 50, 204-210.

EDWARDS, C.G., POWERS, J.R., JENSEN, K.A., WELLER, K.M. \& PETERSON, J.C., 1993. Lactobacillus spp. from Washington State wines: Isolation and characterization. J. Food Sci. 58, 453-458.

ESCHENBRUCH, B. \& DITTRICH, H.H., 1986. Metabolism of acetic acid bacteria in relation to their importance to wine quality. Zentrabl. Mikrobiol. 141, 279289.

FELIX, J.V., PAPATHANASOPOULOS, M.A., SMITH, A.A., VON HOLY, A. \& HASTINGS, J.W., 1994. Characterization of leucocin B-Ta1la: A bacteriocin from Leuconostoc carnosum Ta11a isolated from meat. Curr. Microbiol. 29, 207212.

FLEET, G.H., 1990. Growth of yeasts during wine fermentation. J. Wine Research 1, 211-223.

FLEET, G.H., 1992. Spoilage yeasts. Crit. Reviews Biotech. 12, 1-44.

FLEET, G.H., 1993. The microorganisms of winemaking-Isolation, enumeration and identification. In: FLEET, G.H. (ed). Wine Microbiology and Biotechnology. Harwood Academic Publishers, Chur. pp. 1-25.

FLEET, G.H., 1998. The microbiology of alcoholic beverages. In: WOOD, B.J.B. (ed). Microbiology of Fermented Foods, vol. 1. Blackie Academic \& Professional, London. pp. 217-262.

FLEET, G.H. \& HEARD, G.M., 1993. In: FLEET, G.H. (ed). Wine Microbiology and Biotechnology. Harwood Academic Publishers, Chur. pp. 27-54.

FLEET, G.H., LAFON-LAFOURCADE, S. \& RIBÉREAU-GAYON, P., 1984. Evolution of yeasts and lactic acid bacteria during the fermentation and storage of Bordeaux wines. Appl. Environ. Microbiol. 48, 1034-1038.

FUGELSANG, K.C., 1996. Zygosaccharomyces, a spoilage yeast isolated from wine. CATI August 1996.

FUGELSANG, K.C., 1997. Wine Microbiology. Chapman \& Hall, New York.

FUGELSANG, K.C., 1998. Zygosaccharomyces bailii, a spoilage yeast isolated from grape juice. CATI September 1998.

FUGLSANG, C.C., JOHANSEN, C., CHRISTGAU, S. \& ADLER-NISSEN, J., 1995. Antimicrobial enzymes: Application and future potential in the food industry. Trends Food Sci. Technol. 6, 390-396.

GALLANDER, J.F., 1977. Deacidification of eastern table wines with Schizosaccharomyces pombe. Am. J. Enol.Vitic. 28, 65-68.

GERBAUX, V., MEISTERMANN, E., COTTEREAU, P., BARRIERE, C., CUINIER, C., BERGER, J.L. \& VILLA, A., 1999. Use of lysozyme in enology. Bull. OIV 72, 348-373.

GERBAUX, V., VILLA, A., MONAMY, C. \& BERTRAND, A., 1997. Use of lysozyme to inhibit malolactic fermentation and to stabilize wine after malolactic fermentation. Am. J. Enol. Vitic. 48, 49-54.

GINI, B. \& VAUGHN, R.H., 1962. Characteristics of some bacteria associated with the spoilage of California dessert wines. Am. J. Enol. Vitic. 13, 20-31.

GONZALEZ, C.F. \& KUNKA, B.S., 1987. Plasmid-associated bacteriocin production and sucrose fermentation in Pediococcus acidilactici. Appl. Environ. Microbiol. 53, 2534-2538.

GOSSELÉ, F., SWINGS, J., KERSTERS, K. \& DE LEY, J., 1983a. Numerical analysis of phenotypic features and protein gel electropherograms of Gluconobacter Asai 1935 emend. Int. J. Syst. Bacteriol. 33, 65-81.

GOSSELÉ, F., SWINGS, J., KERSTERS, K., PAUWELS, P. \& DE LEY, J., 1983b. Numerical analysis of phenotypic features and protein gel electrophoregrams of a wide variety of Acetobacter strains. Proposal for the improvement of the taxonomy of the genus Acetobacter Beijerinck 1898, 215. System. Appl. Microbiol. 4, 338-368.

GROISILLIER, A. \& LONVAUD-FUNEL, A., 1999. Comparison of partial malolactic enzyme gene sequences for phylogenetic analysis of some lactic acid bacteria species and relationships with the malic enzyme. Int. J. Syst. Bacteriol. 49, 1417-1428.

GROSSMAN, M.K. \& BECKER, R., 1984. Investigation on bacterial inhibition of wine fermentation. Kellerwirtschaft 10, 272-275.
HASHIMOTO, Y., MIKI, T., MUKAE, M., UEDA, T. \& IMOTO, T., 1998. Construction of a yeast expression system with positive selection for gene insertion in the absence of a specific phenotype. Gene 207, 167-170.

HEARD, G.M. \& FLEET, G.H., 1987. Occurrence and growth of killer yeasts during wine fermentation. Appl. Environ. Microbiol. 53, 2171-2174.

HEARD, G.M. \& FLEET, G.H., 1988. The effect of sulphur dioxide on yeast growth during natural and inoculated wine fermentation. Austr. N.Z. Wine Ind. J. 3, 57-60.

HENICK-KLING, T., 1993. Malolactic fermentation. In: FLEET, G.H. (ed). Wine Microbiology and Biotechnology. Harwood Academic Publishers, Chur. pp. 289326.

HENSCHKE, P.A. \& JIRANEK, V., 1993. Yeasts-Metabolism of nitrogen compounds. In: FLEET, G.H. (ed). Wine Microbiology and Biotechnology. Harwood Academic Publishers, Chur. pp. 77-164.

HERESZTYN, T., 1986a. Metabolism of volatile phenolic compounds from hydroxycinnamic acids by Brettanomyces yeast. Arch. Microbiol. 146, 96-98.

HERESZTYN, T., 1986b. Formation of substituted tetrahydropyridines by species Brettanomyces and Lactobacillus isolated from mousy wines. Am. J. Enol. Vitic. 37, 127-132.

HOLT, J.G., KRIEG, N.R., SNEATH, P.H., STALEY, J.T. \& WILLIAMS, S.T., 1994. Bergey's Manual of Determinative Bacteriology ( $9^{\text {th }} \mathrm{ed}$.). The Williams and Wilkens Co., Baltimore, MD.

HUANG, Y.-C., EDWARDS, C.G., PETERSON, J.C. \& HAAG, K.M., 1996 Relationship between sluggish fermentations and the antagonism of yeast by lactic acid bacteria. Am. J. Enol. Vitic. 47, 1-10.

IBRAHIM, H.R., YAMADA, M., KOBAYASHI, K. \& KATO, A., 1992. Bactericidal action of lysozyme against Gram-negative bacteria due to insertion of a hydrophobic pentapeptide into its C-terminus. Biosci. Biotech. Biochem. 56, 1361-1363.

IBRAHIM, H.R., YAMADA, M., MATSUSHITA, K., KOBAYASHI, K. \& KATO, A., 1994. Enhanced bactericidal action of lysozyme to Escherichia coli by inserting a hydrophobic pentapeptide into its C terminus. J. Biol. Chem. 269, 5059-5063.

IRWIN, D., SUBDEN, R., LAUTENSACH, A. \& CUNNINGHAM, J.D., 1983. Genetic heterogeneity in lactobacilli and leuconostocs of enological significance. Can. Inst. Food Sci. Technol. J. 16, 79-81.

JOYEUX, A., LAFON-LAFOURCADE, S. \& RIBÉREAU-GAYON, P., 1984a Metabolism of acetic acid bacteria in grape must: Consequences on alcoholic and malolactic fermentation. Sci. Aliment. 4, 247-255.

JOYEUX, A., LAFON-LAFOURCADE, S. \& RIBÉREAU-GAYON, P., 1984b. Evolution of acetic acid bacteria during fermentation and storage of wine. Appl. Environ. Microbiol. 48, 153-156.

KANDLER, O., 1983. Carbohydrate metabolism in lactic acid bacteria. Antonie v. Leeuwenhoek 49, 209-224.

KANDLER, O. \& WEISS, N., 1986. Genus Lactobacillus. In: SNEATH, P.H.A., MAIR, N.S., SHARPE, M.E. \& HOLT, J.G. (eds). Bergey's Manual of Systematic Bacteriology, vol. 2. The Williams and Wilkens Co., Baltimore, MD. pp. 12091234.

KATO, A., TAKASAKI, H. \& BAN, M., 1994. Polymannosylation to asparagine19 in hen egg white lysozyme in yeast. FEBS Lett. 355, 76-80.

KREGER-VAN RIJN, N.J.W., 1984. The yeasts, a taxonomic study ( $3^{\text {rd }}$ ed.). Elsevier Science Publishers, Amsterdam.

KUCZYNSKI, J.T. \& RADLER, F., 1982. The anaerobic metabolism of malate of Saccharomyces bailii and the partial purification and characterisation of malic enzyme. Arch. Microbiol. 131, 266-270.

KUENSCH, U., TEMPERLI, A. \& MAYER, K., 1974. Conversion of arginine to ornithine during malolactic fermentation in a red Swiss wine. Am. J. Enol. Vitic. 25, 191-193.

KUNKEE, R.E., 1991. Some roles of malic acid in the malolactic fermentation in winemaking. FEMS Microbiol. Rev. 88, 55-72.

KUNKEE, R.E. \& BISSON, L., 1993. Winemaking yeasts. In: ROSE, A.H. \& HARRISON, J.S. (eds). The Yeasts ( $2^{\text {nd }}$ ed.), vol. 5: Yeast technology. Academic Press, London. pp. 69-128.

KURTZMAN, C.P. \& FELL, J.W., 1998. The yeasts, a taxonomic study (4th ed.). Elsevier Science Publishers, Amsterdam.

LAFON-LAFOURCADE, S., 1975. L'histamine des vins. Connaiss. Vigne Vin. 9 , 103-115.

LAFON-LAFOURCADE, S., CARRE, E. \& RIBÉREAU-GAYON, P., 1983. Occurrence of lactic acid bacteria during the different stages of vinification and conservation of wines. Appl. Environ. Microbiol. 46, 874-880. 
LAMBRECHTS, M.G. \& PRETORIUS, I.S., 2000. Yeast and its importance to wine aroma - A Review. S. Afr. J. Enol. Vitic. (in press).

LE JEUNE, C., LONVAUD-FUNEL, A., TEN BRINK, B., HOFSTRA, H. \& VAN DER VOSSEN, J.M.B.M., 1995. Development of a detection system for histidine decarboxylating lactic acid bacteria based on DNA probes, PCR and activity test. J. Appl. Bacteriol. 78, 316-326.

LEE, T.H. \& SIMPSON, R.F., 1993. Microbiology and chemistry of cork taints in wine. In: FLEET, G.H. (ed). Wine Microbiology and Biotechnology. Harwood Academic Publishers, Chur. pp. 353-372.

LEE, T.H., SIMPSON, R.F., VANDEPEER, J., FLEET, G.H., DAVIS, C.R., DALY, N. \& YAP, A., 1984. Microbiology of wine corks. In: LEE, T.H. \& SOMERS, T.C. (eds). Advance in Viticulture and Oenology for Economic Gain. The Australian Wine Research Institute. pp. 435-450.

LEFEBVRE, A., RIBOULET, J.M., BIODRON, J.N. \& RIBEREAU-GAYON, P., 1983. Incidence des micro-organismes du liège sur les alterations olfatives du vin. Sci. Aliment. 3, 265-278.

LIU, S.-Q. \& PILONE, G.J., 1998. A Review: Arginine metabolism in wine lactic acid bacteria and its practical significance. J. Appl. Microbiol. 84, 315-327.

LIU, S.-Q., DAVIS, C.R. \& BROOKS, J.D., 1995b. Growth and metabolism of selected lactic acid bacteria in synthetic wine. Am. J. Enol. Vitic. 46, 166-174.

LIU, S.-Q., PRITCHARD, G.G., HARDMAN, M.J. \& PILONE, G.J., 1994. Citrulline production and ethyl carbamate (urethane) precursor formation from arginine degradation by wine lactic acid bacteria Leuconostoc oenos and Lactobacillus buchneri. Am. J. Enol. Vitic. 45, 235-242.

LIU, S.-Q., PRITCHARD, G.G., HARDMAN, M.J. \& PILONE, G.J., 1995a. Occurrence of arginine deiminase pathway enzymes in arginine catabolism by wine lactic acid bacteria. Appl. Environ. Microbiol. 61, 310-316.

LIU, S.-Q., PRITCHARD, G.G., HARDMAN, M.J. \& PILONE, G.J., 1996. Arginine catabolism in wine lactic acid bacteria: is it via the arginine deiminase pathway or the arginase-urease pathway? J. Appl. Bacteriol. 81, 486-492.

LLAUBÈRES, R.M., RICHARD, B., LONVAUD, A. \& DUBOURDIEU, D., 1990. Structure of an exocellular b-D-glucan from Pediococcus sp., a wine lactic acid bacteria. Carbohyd. Res. 203, 103-107.

LONVAUD-FUNEL, A., 1995. Microbiology of the malolactic fermentation: Molecular aspects. FEMS Microbiol. Lett. 126, 209-214.

LONVAUD-FUNEL, A., 1999. Lactic acid bacteria in the quality improvement and depreciation of wine. Antonie v. Leeuwenhoek 76, 317-331.

LONVAUD-FUNEL, A. \& JOYEUX, A., 1988. Une altérarion bactérienne des vins: la 'maladie des vins filants'. Sci. Aliment. 8, 33-49.

LONVAUD-FUNEL, A. \& JOYEUX, A., 1993. Antagonisms between lactic acid bacteria of wines: Inhibition of Leuconostoc oenos by Lactobacillus plantarum and Pediococcus pentosaceus. Food Microbiol. 10, 411-419.

LONVAUD-FUNEL, A. \& JOYEUX, A., 1994. Histamine production by wine lactic acid bacteria: Isolation of a histamine-producing strain of Leuconostoc oenos. J. Appl. Bacteriol. 77, 401-407.

LONVAUD-FUNEL, A., JOYEUX, A. \& DESENS, C., 1988. The inhibition of malolactic fermentation of wines by products of yeast metabolism. J. Food Sci. Technol. 44, 183-191.

LONVAUD-FUNEL, A., FREMAUX, C., BITEAU, N. \& JOYEUX, A., 1991 a. Speciation of lactic acid bacteria from wines by hybridization with DNA probes. Food Microbiol. 8, 215-222.

LONVAUD-FUNEL, A., JOYEUX, A. \& LEDOUX, A., 1991b. Specific enumeration of lactic acid bacteria in fermenting grape must and wine by colony hybridization with non-isotopic DNA probes. J. Appl. Bacteriol. 71, 501-508.

LONVAUD-FUNEL, A., GUILLOUX, Y. \& JOYEUX, A., 1993. Isolation of a DNA probe for identification of glucan-producing Pediococcus damnosus in wines. J. Appl. Bacteriol. 74, 41-47.

MANCA DE NADRA, M.C. \& STRASSER DE SAAD, A.M., 1995. Polysaccharide production by Pediococcus pentosaceus from wine. Int. J. Food Microbiol. 27, 101-106.

MARGALITH, P.Z., 1981. Flavour Microbiology. GC Thomas Publishers, Springfield, IL. pp. 173-224.

MARIETTE, I., SCHWARZ, E., VOGEL, R.F. \& HAMMES, W.P., 1991. Characterization by plasmid profile analysis of acetic acid bacteria from wine, spirit and cider acetators from industrial vinegar production. J. Appl. Bacteriol. 71, 134-138.

MARTINEAU, B. \& HENICK-KLING, T., 1995. Performance and diacetyl production of commercial strains of malolactic bacteria in wine. J. Appl. Bacteriol. 78, 526-536.
MARUGG, J.D., GONZALEZ, C.F., KUNKA, B.S., LEDEBOER, A.M., PUCCI, M.J., TOONEN, M.Y., WALKER, S.A., ZOETMULDER, L.C.M. \& VANDERBERGH, P.A., 1992. Cloning, expression and nucleotide sequence of genes involved in production of pediocin PA-1, a bacteriocin from Pediococcus acidilactici PAC1.0. Appl. Environ. Microbiol. 58, 2360-2367.

MARX, H.T. \& SABALITSCHKA, T., 1965. Zur Unbeständigkeit der Sorbinsäure. Seifen Öle Fette Wachse 91, 720-722.

MCGREW, J.R., 1982. Fungal diseases: a factor in vine culture. Dev. Ind. Microbiol. 23, 87-90.

MONTEIRO, F.F. \& BISSON, L.F., 1991. Amino acid utilization and urea formation during vinification fermentations. Am. J. Enol.Vitic. 40, 1-8.

MONTVILLE, T.J. \& KAISER, A.L., 1993. Antimicrobial proteins: Classification, nomenclature, diversity, and relationship to bacteriocins. In: HOOVER, D.G. \& STEENSON, L.R. (eds). Bacteriocins of Lactic Acid Bacteria. Academic Press, San Diego, USA. pp. 1-22.

MURRELL, W.G. \& RANKINE, B.C., 1979. Isolation and identification of a sporing Bacillus from bottled brandy. Am. J. Enol. Vitic. 30, 247-249.

NAKAMURA, S., TAKASAKI, H., KOBAYASHI, K. \& KATO, A., 1993. Hyperglycosylation of hen egg white lysozyme in yeast. J. Biol. Chem. 268, 12706-12712.

NES, I.F., DIEP, D.B., HÅVARSTEIN, L.S., BRURBERG, M.B., EIJSINK, V. \& HOLO, H., 1996. Biosynthesis of bacteriocins in lactic acid bacteria. Antonie van Leeuwenhoek 70, 113-128.

NETTLES, C.G. \& BAREFOOT, S.F., 1993. Biochemical and genetic characteristics of bacteriocins of food-associated lactic acid bacteria. J. Food Protect. 56, 338-356.

NIELSEN, J.C. \& PRAHL, C., 1997. Metabolism of citric acid by Leuconostoc oenos in direct inoculation. Effect on wine flavour. Wynboer 11, 84-85.

OUGH, C.S., 1971. Measurement of histamine in California wines. J. Agric. Food Chem. 19, 241-244.

OUGH, C.S., 1976. Ethyl carbamate in fermented beverages and foods. I. Naturally occuring ethyl carbamate. J. Agric. Food Chem. 24, 323-328.

OUGH, C.S., 1993. Ethyl carbamate in foods and wine. Bulletin of the Society of Medical Friends of Wine 25, 7-8.

OUGH, C.S. \& KUNKEE, R.E., 1974. The effect of fumaric acid on malolactic fementation in wine from warm areas. Am. J. Enol. Vitic. 25, 188-190.

OUGH, C.S., CROWELL, E.A. \& GUTLOVE, B.R., 1988a. Carbamyl compound reactions with ethanol. Am. J. Enol. Vitic. 39, 239-242.

OUGH, C.S., CROWELL, E.A. \& MOONEY, L.A., 1988b. Formation of ethyl carbamate precursors during grape juice (Chardonnay) fermentation. I. Addition of amino acids, urea and ammonia: effects of fortification on intracellular and extracellular precursors. Am. J. Enol. Vitic. 39, 243-249.

OUGH, C.S., HUANG, Z., AN, D. \& STEVENS, D., 1991. Amino acid uptake by four commercial yeasts at two different temperatures of growth and fermentation: Effects on urea excretion and readsorption. Am. J. Enol. Vitic. 41, 26-41.

PAPATHANASOPOULOS, M.A., KRIER, F., REVOL-JUNELLES, A-M., LEFEBVRE, G., LE CAER, J.P., VON HOLY, A. \& HASTINGS, J.W., 1997. Multiple bacteriocin production by Leuconostoc mesenteroides TA33a and other Leuconostoc/Weissella strains. Curr. Microbiol. 35, 331-335.

PEARSON, R.C., 1990. Current research on grape fungal diseases and their control in New York. Austr. N.Z. Wine Ind. J. 5, 206-209.

PEARSON, R.C. \& GOHEEN, A.C., 1994. Compendium of Grape Diseases. APS Press, St. Paul, Minnesota.

PETERING, J.E., SYMONS, M.R., LANGRIDGE, P. \& HENSCHKE, P.A., 1991. Determination of killer yeast activity in fermenting grape juice by using a marked Saccharomyces wine yeast strain. Appl. Environ. Microbiol. 57, 32323236.

PEYNAUD, E. \& DOMERQ, S., 1959. A review of microbiological problems in winemaking in France. Am. J. Enol. Vitic. 10, 69-77.

PILONE, G.J., CLAYTON, M.G. \& VAN DUIVENBODEN, R.J., 1991. Characterization of wine lactic acid bacteria: Single broth culture for tests of heterofermentation, mannitol from fructose, and ammonia from arginine. Am. $J$. Enol.Vitic. 42, 153-157.

PORTER, L.J. \& OUGH, C.S., 1982. The effects of ethanol, temperature and dimethyldicarbonate on viability of Saccharomyces cerevisiae Montrachet No. 522 in wine. Am. J. Enol. Vitic. 33, 222-225.

PRETORIUS, I.S., 1999. Engineering designer genes for wine yeasts. Austr: N.Z. Wine Indust. J. 14, 42-47.

PRETORIUS, I.S., 2000. Tailoring wine yeast for the new millennium: Novel approaches to the ancient art of winemaking. Yeast 16, 675-729. 
PRETORIUS, I.S., VAN DER WESTHUIZEN, T.J. \& AUGUSTYN, O.P.H., 1999. Yeast biodiversity in vineyards and wineries and its importance to the South African wine industry. S. Afr. J. Enol. Vitic. 20, 61-74.

QUADRI, L.E.N., SAILER, M., TEREBIZNIK, M.R., ROY, K.L., VEDERAS, J.C. \& STILES, M.E., 1995. Characterization of the protein conferring immunity to the antimicrobial peptide carnobacteriocins B2 and BM1. J. Bacteriol. 179, 1144-1151.

RADLER, F., 1976. Degradation de l'acide sorbique par les bacteries. Bull. OIV 49, 629-635.

RADLER, F., 1990a. Possible use of nisin in winemaking. I. Action of nisin against lactic acid bacteria and wine yeasts in solid and liquid media. Am. J. Enol. Vitic. 41, 1-6.

RADLER, F., 1990b. Possible use of nisin in winemaking. II. Experiments to control lactic acid bacteria in the production of wine. Am. J. Enol. Vitic. 41, 7-11.

RADLER, F., 1993. Yeasts-Metabolism of organic acids. In: FLEET, G.H. (ed). Wine Microbiology and Biotechnology. Harwood Academic Publishers, Chur. pp. $165-182$

RADLER, F. \& SCHMITT, M., 1987. Killer toxins of yeasts: Inhibitors of fermentation and their adsorption. J. Food Protect. 50, 234-238.

RADLER, F. \& YANNISSIS, C., 1972. Weinsäureabbau bei Milchsäurebakterien. Arch. Microbiol. 82, 219-238.

RANKINE, B.C., FORNACHON, J. \& BRIDSON, D.A., 1969. Diacetyl in Australian dry red wines and its significance in wine quality. Vitis 8, 129-134.

RAUHUT, D., 1993. Yeasts-Production of sulfur compounds. In: FLEET, G.H. (ed). Wine Microbiology and Biotechnology. Harwood Academic Publishers, Chur. pp. 183-223.

RAUHUT, D., KÜRBEL, H., DITTRICH, H.H. \& GROSSMANN, M.K., 1996. Properties and differences of commercial yeast strains with respect to their formation of sulfur compounds. Vitic. Enol. Sci. 51, 187-192.

RIVAS-GONZALO, J.C., SANTOS-HERNANDEZ, J.F. \& MARINÉ-FONT, A., 1983. Study of the evolution of tyramine content during the vinification process. J. Food Sci. 48, 417-418.

RODRIGUEZ, S.B. \& THORNTON, R.J., 1990. Factors influencing the utilisation of L-malate by yeasts. FEMS Microbiol. Lett. 60, 17-22.

ROMANO, P. \& SUZZI, G., 1993. Sulfur dioxide and wine microorganisms. In: FLEET, G.H. (ed). Wine Microbiology and Biotechnology. Harwood Academic Publishers, Chur. pp. 373-393.

ROSE, A.H., 1987. Responses to the chemical environment. In: ROSE, A.H. \& HARRISON, J.S. (eds). The Yeasts ( ${ }^{\text {nd }}$ ed.), vol. 2: Yeasts and the environment. Academic Press, London. pp. 5-40.

SAGUIR, F.M. \& MANCA DE NADRA, M.C., 1996. Organic acid metabolism under different glucose concentrations of Leuconostoc oenos from wine. J. Appl. Bacteriol. 81, 393-397.

SCHILLINGER, U., 1990. Bacteriocins of lactic acid bacteria,. In: BILL, D.D. \& KUNG, S. (eds). Biotechnology and Food Safety. Butterworth-Heinemann, Boston, MA. pp. 55-74.

SCHOEMAN, H., VIVIER, M.A., DU TOIT, M., DICKS, L.M.T. \&. PRETORIUS, I.S., 1999. The development of bactericidal yeast strains by expressing the Pediococcus acidilactici pediocin gene (pedA) in Saccharomyces cerevisiae. Yeast 15, 647-656

SCHUTTE, L., 1975. Precursors of sulfur-containing flavor compounds. In: FURIA, T.E. \& BELLENCA, N. (eds). Fenaroli's Handbook of Flavor Ingredients. CRC Press, Cleveland, Ohio. pp. 184-227.

SCHÜTZ, H. \& RADLER, F., 1984. Anaerobic reduction of glycerol to propandiol-1,3 by Lactobacillus buchneri. System. Appl. Microbiol. 5, 169-178.

SCOTT, P.M., FULEKI, T. \& HARWIG, J., 1977. Patulin content of juice and wine produced from moldy grapes. J. Agric. Food Chem. 25, 434-437.

SHIMAZU, Y. \& WATANABE, M., 1981. Effects of yeast strains and environmental conditions on forming of organic acids in must during fermentation. $J$. Ferment. Technol. 59, 27-32.

SHIMIZU, K., 1993. Killer yeasts. In: FLEET, G.H. (ed). Wine Microbiology and Biotechnology. Harwood Academic Publishers, Chur. pp. 243-263.

SIEVERS, M., GABERTHÜEL, C., BOESCH, C., LUDWIG, W. \& TEUBER, M., 1995. Phylogenetic position of Gluconobacter species as a coherent cluster separated from all Acetobacter species on the basis of $16 \mathrm{~S}$ ribosomal RNA sequences. FEMS Microbiol. Lett. 126, 123-126.

SIEVERS, M., LUDWIG, W. \& TEUBER, M., 1994. Phylogenetic positioning of Acetobacter, Gluconobacter, Rhodopila and Acidiphilium species as a branch of acidophilic bacteria in the a-subclass of Proteobacteria based on 16S ribosomal DNA sequences. System. Appl. Microbiol. 17, 189-196.
SIEVERS, M., SELLMER, S. \& TEUBER, M., 1992. Acetobacter europaeus sp. nov., a main component of industrial vinegar fermenters in Central Europe. System. Appl. Microbiol. 15, 386-392.

SLININGER, P.J., BOTHAST, R.J. \& SMILEY, K.L., 1983. Production of 3hydroxypropionaldehyde from glycerol. Appl. Environ. Microbiol. 46, 62-67.

SNOW, R., 1983. Genetic improvement of wine yeast. In: SPENCER, J.T.F., SPENCER, D.M. \& SMITH, A.R.W. (eds). Yeast Genetics-Fundamental and Applied Aspects. Springer-Verlag, New York. pp. 439-459.

SOHIER, D. \& LONVAUD-FUNEL, A., 1998. Rapid and sensitive in situ hybridization method for detecting and identifying lactic acid bacteria in wine. Food Microbiol. 15, 391-397.

SOHIER, D., COULON, J. \& LONVAUD-FUNEL, A., 1999. Molecular identification of Lactobacillus hilgardii and genetic relatedness with Lactobacillus brevis. Int. J. Syst. Bacteriol. 49, 1075-1081.

SOKOLLEK, S.J., HERTEL, C. \& HAMMES, W.P., 1998. Description of Acetobacter oboediens sp. nov. and Acetobacter pomorum sp. nov., two new species isolated from industrial vinegar fermentations. Int. J. Syst. Bacteriol. 48, 935-940.

SOLES, R.M., OUGH, C.S. \& KUNKEE, R.E., 1982. Ester concentration difference in wine fermented by various species and strains of yeast. Am.J. Enol. Vitic. 33, 94-98.

SOUFLEROS, E., BARRIOS, M-L. \& BERTAND, A., 1998. Correlation between the content of biogenic amines and other wine compounds. Am. J. Enol. Vitic. 49, 266-278

SPLITTSTOESSER, D.F. \& CHURNEY, J.J., 1992. The incidence of sorbic acidresistant Gluconobacter and yeasts on grapes grown in New York State. Am. J. Enol. Vitic. 43, 290-293.

SPONHOLZ, W.R., 1989. Fehlerhafte und unerwünschte Erscheinungen in Wein. In: WÜRDIG, G. \& WOLLER, R. (eds). Chemie des Weines. Stuttgart: Ulmer. pp. $385-411$

SPONHOLZ, W.R., 1993. Wine spoilage by microorganisms. In: FLEET, G.H. (ed). Wine Microbiology and Biotechnology. Harwood Academic Publishers, Chur. pp. 395-420.

SPONHOLZ, W.R. \& DITTRICH, H.H., 1974. Die Bildung von $\mathrm{SO}_{2}$ bindenden Gärungsnebenprodukten, höheren Alkoholen und Estern bei einigen Reinzuchthefestämmen und bei einigen für die weinbereitung wichtigen "wilden" Hefen. Wein-Wissenschaft 29, 301-314.

SPONHOLZ, W.R., DITTRICH, H.H. \& HAN, K., 1990. Die Beeinflussung der Gärung und der Essigsäureethylester-bildung durch Hanseniaspora uvarum. Vit. Enol. Sci. 45, 65-72.

SPONHOLZ, W.R., KURBEL, H. \& DITTRICH, H.H., 1991. Beitrage zur bildung von ethyl carbamate im wein. Wein-Wissenschaft 46, 11-17.

STEVENS, D.F. \& OUGH, C.S., 1993. Ethyl carbamate formation: Reaction of urea and citrulline with ethanol in wine under low to normal temperature conditions. Am. J. Enol. Vitic. 44, 309-312.

STILES, M.E. \& HOLZAPFEL, W.H., 1997. Lactic acid bacteria of foods and their current taxonomy. Int. J. Food Microbiol. 36, 1-29.

STRASSER DE SAAD, A.M. \& MANCA DE NADRA, M.C., 1992. Sugar and malic acid utilization and acetic acid formation by Leuconostoc oenos. W. J. Microbiol.Biotech. 8, 280-283.

STRASSER DE SAAD, A.M., PASTERIS, S.E. \& MANCA DE NADRA, M.C., 1995. Production and stability of pediocin N5p in grape juice medium. J. Appl. Bacteriol. 78, 473-476.

SWINGS, J., 1992. The Genera Acetobacter and Gluconobacter. In: BARLOW, A., TRÜPER, H.G., DWORKIN, M., HARDER, W. \& SCHLEIFER, K.-H. (eds). The Prokaryotes ( $2^{\text {nd }}$ ed.). Springer-Verlag, New York. pp. 2268-2286.

TERRELL, R.R., MORRIS, J.R., JOHNSON, M.G., GBUR, E.E. \& MAKUS, D.J., 1993. Yeast inhibition in grape juice containing sulfur dioxide, sorbic acid and dimethyldicarbonate. J. Food Sci. 58, 1132-1135.

TEUBER, M., SIEVERS, M. \& ANDERSEN, A., 1987. Characterization of the microflora of high acid submerged fermenters by distinct plasmid profiles. Biotech. Lett. 9, 265-268.

THOMAS, D.S., 1993. Yeast as spoilage organisms in beverages. In: ROSE, A.H. \& HARRISON, J.S. (eds). The Yeasts $\left(2^{\text {nd }}\right.$ ed.), vol. 5: Yeast technology. Academic Press, New York. pp. 517-561

THOMAS, S. \& DAVENPORT, R.R., 1985. Zygosaccharomyces bailii-a profile of characteristics and spoilage activities. Food Microbiol. 2, 157-169.

TRACEY, R.P. \& BRITZ, T.J., 1987. A numerical taxonomic study of Leuconostoc oenos strains from wine. J. Appl. Bacteriol. 63, 523-532. 
TRANTER, H.S., 1994. Lysozyme, Ovotransferin and Avidin. In: DILLON, V.M. \& BOARD, R.G. (eds). Natural Antimicrobial Systems and Food Preservation. CAB International, Oxon. pp. 65-97.

USSEGLIO-TOMASSET, L., 1992. Properties and use of sulphur dioxide. Food Addit. Contam. 9, 399-404.

VAN VUUREN, H.J.J. \& WINGFIELD, B.D., 1986. Killer yeasts cause of stuck fermentations in a wine cellar. S. Afr. J. Enol. Vitic. 7, 113-118.

VAUGHN, R.H., 1955. Bacterial spoilage of wines with special reference to California conditions. Adv. Food Res. 6, 67-108.

VENEMA, K., KOK, J., MARUGG, J.D., TOONEN, M.Y., LEDEBOER, A.M., VENEMA, G. \& CHIKINDAS, M.L., 1995. Functional analysis of the pediocin operon of Pediococcus acidilactici PAC1.0: PedB is the immunity protein and PedD is the precursor processing enzyme. Mol. Microbiol. 17, 515-522.

VIDAL-CAROU, M.C., AMBATLLE-ESPUNYES, A., ULLA-ULLA, M.C. \& MARINÉ-FONT, A., 1990a. Histamine and tyramine in Spanish wines: Their formation during the winemaking process. Am. J. Enol. Vitic. 41, 160-167.

VIDAL-CAROU, M.C., CODONY-SALCEDO, R. \& MARINÉ-FONT, A., 1990b. Histamine and tyramine in Spanish wines: Relationships with total sulfur dioxide level, volatile acidity and malo-lactic fermentation intensity. Food Chem. 35, 217-227.

WEILLER, H.G. \& RADLER, R., 1976. On the metabolism of amino acids by lactic acid bacteria isolated from wine. Z. Lebensm.-Unters. Forsch. 161, 259266.

WENZEL, K., DITTRICH, H.H., SEYFFARDT, H.P. \& BOHNERT, J., 1980 Schwefelrückstände auf Trauben und im Most und ihr Einfluß auf die $\mathrm{H}_{2} \mathrm{~S}$ Bildung. Wein-Wissenschaft 35, 414-420.

WIBOWO, D., ESCHENBUCH, R., DAVIS, C., FLEET, G.H. \& LEE, T.H., 1985. Occurrence and growth of lactic acid bacteria in wine-A review. Am. $J$. Enol. Vitic. 36, 302-313.
WILKER, K.L. \& DHARMADHIKARI, M.R., 1997. Treatment of barrel wood infected with acetic acid bacteria. Am. J. Enol. Vitic. 48, 516-520.

YAMADA, Y. \& KONDO, K., 1984. Gluconoacetobacter, a new sub-genus comprising acetate-oxidizing acetic acid bacteria with ubiquinone-10 in the genus Acetobacter. J. Gen. Appl. Microbiol. 30, 297-303.

YAMADA, Y., HOSHINO, K. \& ISHIKAWA, T., 1997. The phylogeny of acetic acid bacteria based on the partial sequences of $16 \mathrm{~S}$ ribosomal RNA: The elevation of the subgenus Gluconoacetbacter to generic level. Biosci. Biotech. Biochem. 61, 1244-1251.

YAMADA, Y., ITAKURA, N., YAMASHITA, M. \& TAHARA, Y., 1984. Deoxyribonucleic acid homologies in strains of Gluconobacter species. $J$. Ferment. Technol. 62, 595-600.

YAMADA, Y., NUNODA, M., ISHIKAWA, T. \& TAHARA, Y., 1981. The cellular fatty acid composition in acetic acid bacteria. J. Gen. Appl. Microbiol. 27, 405417.

ZAPPAROLI, G., TORRIANI, S., PESENTE, P. \& DELlaGLIO, F., 1998. Design and evaluation of malolactic enzyme gene targeted primers for rapid identification and detection of Oenococcus oeni in wine. Leett. Appl. Microbiol. 27, 243-246.

ZEE, J.A., SIMARD, R.E., L'HEUREUX, L. \& TREMBLAY, J., 1983. Biogenic amines in wines. Am. J. Enol. Vitic. 34, 6-9.

ZIMMERLI, B. \& DICK, R., 1996. Ochratoxin A in table wine and grape-juice: occurrence and risk assessment. Food Addit. Contam. 13, 655-668.

ZOECKLEIN, B.W., FUGELSANG, K.C., GUMP, B.H. \& NURY, F.S., 1995. Wine Analysis and Production. Chapman \& Hall, New York. 